\title{
Ecological and Plant Community Implication on Essential Oils Composition in Useful Wild Officinal Species: A Pilot Case Study in Apulia (Italy)
}

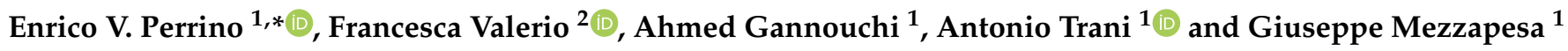 \\ 1 CIHEAM, Mediterranean Agronomic Institute of Bari, Via Ceglie 9, 70010 Valenzano, Italy; \\ ahmedghannouchi01@yahoo.com (A.G.); trani@iamb.it (A.T.); mezzapesa@iamb.it (G.M.) \\ 2 Institute of Sciences of Food Production (ISPA), National Research Council, Via Amendola 122/O, \\ 70126 Bari, Italy; francesca.valerio@ispa.cnr.it \\ * Correspondence: perrino@iamb.it or enricoperrino@gmail.com
}

Citation: Perrino, E.V.; Valerio, F.; Gannouchi, A.; Trani, A.; Mezzapesa, G. Ecological and Plant Community Implication on Essential Oils Composition in Useful Wild Officinal Species: A Pilot Case Study in Apulia (Italy). Plants 2021, 10, 574. https:// doi.org/10.3390/plants10030574

Academic Editor: Othmane Merah

Received: 1 March 2021

Accepted: 16 March 2021

Published: 18 March 2021

Publisher's Note: MDPI stays neutral with regard to jurisdictional claims in published maps and institutional affiliations.

Copyright: (c) 2021 by the authors. Licensee MDPI, Basel, Switzerland. This article is an open access article distributed under the terms and conditions of the Creative Commons Attribution (CC BY) license (https:/ / creativecommons.org/licenses/by/ $4.0 /)$.

\begin{abstract}
The study focused on the effects of ecology (plant communities and topographical data) on composition of essential oils (EOs) of some officinal wild plant species (Lamiales): Clinopodium suaveolens, Salvia fruticosa subsp. thomasii, Satureja montana subsp. montana, and Thymbra capitata, in different environments of Apulia (Italy). C. suaveolens and S. fruticosa subsp. thomasii are rare species of conservation interest, while $S$. montana subsp. montana and T. capitata, have a wide distribution and are used in traditional medicine or as spices. Results showed that the ecological context (phytosociological and ecological features) may influence the composition of EOs of the studied species. High differences in the compound composition have been found in S. montana subsp. montana, whereas minor effects were observed in C. suaveolens, S. fruticosa subsp. thomasii, and $T$. capitata accessions. The understanding of such aspects is necessary for providing optimal conditions to produce EOs rich in compounds known for their biological activities. The results are of great interest also for EOs producers and at the same time to improve our knowledge and valorize wild officinal plants.
\end{abstract}

Keywords: correlation; ecology; essential oils; lamiaceae; vegetation

\section{Introduction}

For thousands of years, humans used natural ecosystems for the purpose of their survival [1]. Wild medicinal and aromatic plants were and still are a great resource for the daily life of populations [2,3]. They were and are used as food, spices, cosmetics, and perfumes in religious rituals and to treat illnesses and relieve pain [4]. Hence, historically the use of these wild plants became a significant aspect of populations' cultural heritage becoming real traditions that kept on from one generation to another $[5,6]$.

Plants, as is well known, are influenced by a range of intrinsic and extrinsic factors, which especially in officinal plants can induce changes in the chemical composition and physiological activities of their essential oils. In fact, it is well documented that the same species, under different environmental and geographical conditions, can produce essential oils with different chemical profiles and biological properties [7-9]. However, with the exception of some studies showing a strong correlation between vegetation and heavy metal concentration in soil [10], it seems that there is lack of data on the effect of other important ecological factors, such as plant communities on plant metabolites. Furthermore, despite the great value of some plants as sources of bioactive compounds, important for several applications, many of them are rare and endemic species and have not yet been investigated for their ecology, chemical complexity, and the biological properties of their extracts.

Most of the species belonging to the Lamiaceae family (formerly known as Labiatae) are aromatic and possess antioxidant compounds [10,11] and essential oils useful 
for defense of the plants against insects $[12,13]$ and making them valuable in cosmetics, perfumery, agriculture, and medicine $[14,15]$. Indeed, they are widely used in traditional medicine as a cure for many disorders [15], in relation with their global wide distribution, particularly in the Mediterranean region [16], and relative easy propagation. Among the shrub species, they have also high beekeeping importance, at least in the Mediterranean environment, with a few other families such as Ericaceae, Fabaceae (formerly known as Leguminosae), and Rosaceae [17].

The present research focused on four wild taxa, Thymbra capitata (L.) Cav., Salvia fruticosa Mill. subsp. thomasii (Lacaita) Brullo, Guglielmo, Pavone \& Terrasi, Satureja montana L. subsp. montana, and Clinopodium suaveolens (Sm.) Kuntze in order to: (1) analyze the essential oils (EOs) extracts from the selected species by GC/MS; (2) assess any relationship between the essential oils composition and the ecological context, especially of plant communities.

\section{Study Area}

The studied areas are located in the centre of Apulia (Figure 1), which is one of the most important agricultural areas in Italy. Eight sites, two for each species, were found so distributed: Salvia fruticosa subsp. thomasii at "Gravine Arco Jonico" (Taranto), near Masseria Gaudella (Laterza, Taranto) and in Gravina del Petruscio (Mottola, Taranto); Thymbra capitata at Gravina Capo di Gavito (Mottola, Taranto) and Torre Santa Sabina (Carovigno, Brindisi); Satureja montana subsp. montana at Difesa di Malta (Fasano, Bari) and Monte Castiglione (Altamura, Bari); Clinopodium suaveolens at Scannapecora (Altamura, Bari) and Jazzo Filieri (Poggiorsini, Bari).

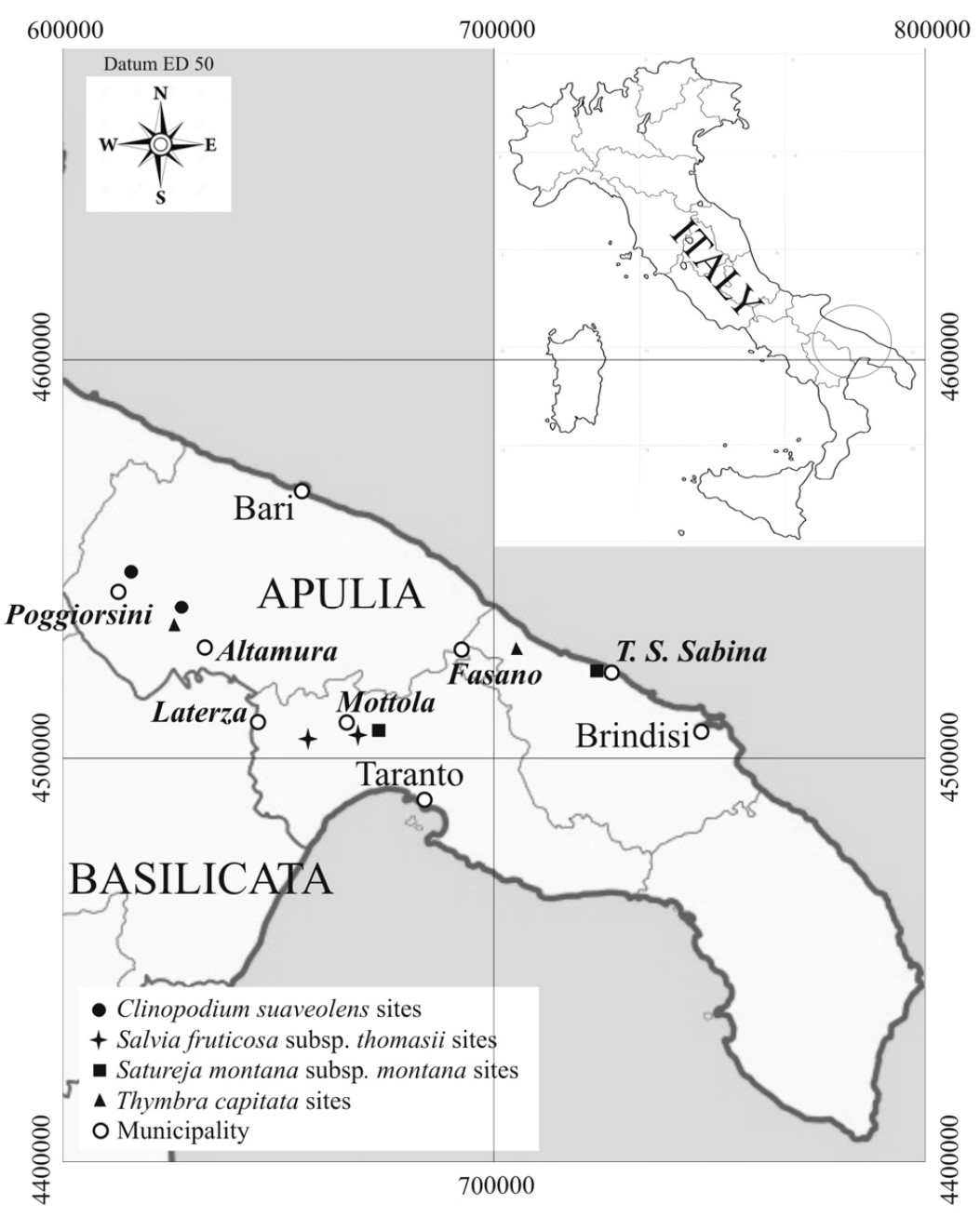

Figure 1. Sites location of the studied officinal wild species. 
Within the sites in the province of Taranto, the most widespread pedotype is Lithic Ruptic-Inceptic Haploxeralf fine, predominantly clayey, very thin, and very rocky with substrate within $50 \mathrm{~cm}$ [18], and in particular at Gravina del Petruscio, Gravina Capo di Gavito, and near Masseria Gaudella, as also at Scannapecora and Jazzo Filieri in the province of Bari, the geological type is that of Skeletal limestones of neritic and carbonate platform facies (Upper Cretaceous) (Geological and Geolithological maps), on Tyrrhenian carbonate reliefs with material defined by calcareous sedimentary rocks and climate from Oceanic to Suboceanic Mediterranean partially mountainous (Ecopedologic map). The Monte Castiglione site shares the same geolithology as the Taranto and Bari sites but with different ecopedology, ascribable to hilly reliefs with undifferentiated tertiary sedimentary rocks and a sub-continental Mediterranean to continental Mediterranean climate (Ecopedologic map). The Torre Santa Sabina and Difesa di Malta sites share the same ecopedology as the Monte Castiglione site (Ecopedologic map) but with Terrigenus-skeletal limestones like "Panchina" (Pleistocene) (Geological and Geolithological maps) (Italian Ministry for the Environment, Land and Sea, http:/ / www.pcn.minambiente.it/viewer, accessed on 18 November 2020) [19].

\section{Materials and Methods}

\subsection{Vegetation Analysis}

The field inspections of the four studied species (Clinopodium suaveolens, Salvia fruticosa subsp. thomasii, Satureja montana subsp. montana, Thymbra capitata) were carried out in 2019. A total of eight vegetation surveys were conducted in two different sites for each species, following the phytosociological method of the Zurich-Montpellier school [20]. Identification code, taxon, location, date, geographic position (expressed in WGS84-World Geodetic System 1984)) are reported in Table 1, while phytosociological and topographical data (Identification code, altitude (m. a. s.), aspect, slope $\left({ }^{\circ}\right)$, relevé area $\left(\mathrm{m}^{2}\right)$, stoniness $(\%)$, rockiness $(\%)$, cover total (\%), and geolithological and ecopedologic type), endemicity, number of species identified, number of individuals collected for laboratory analyses, are reported in Tables 2-4. Other species identified and recorded but not used for the phytosociological classification are here not reported. However, a total of 8 specimens for each species and for each reléve, were collected and deposited at the official herbarium of Bari University (Italy) (Herbarium Horti Botanici Barensis, BI). In conclusion, the possible experimental design was 4 species $\times 2$ sites per species $x$ several but variable number of individuals per specimen (Tables 2-4).

Table 1. Identificative code (IC), location, date relief, and geographical position of each taxon.

\begin{tabular}{|c|c|c|c|c|}
\hline IC & Taxon & Location & Data Relief & Geographic Position (WGS84) \\
\hline Cs1 & \multirow{2}{*}{ Clinopodium suaveolens (Sm.) Kuntze } & $\begin{array}{c}\text { Scannapecora } \\
\text { (Altamura, Bari) }\end{array}$ & 17.04 .19 & $\begin{array}{l}40^{\circ} 54^{\prime} 19^{\prime \prime} \mathrm{N} \\
16^{\circ} 26^{\prime} 32^{\prime \prime} \mathrm{E}\end{array}$ \\
\hline Cs2 & & $\begin{array}{c}\text { Jazzo Filieri } \\
\text { (Poggiorsini, Bari) }\end{array}$ & 17.04 .19 & $\begin{array}{l}40^{\circ} 56^{\prime} 37^{\prime \prime} \mathrm{N} \\
16^{\circ} 16^{\prime} 23^{\prime \prime} \mathrm{E}\end{array}$ \\
\hline Sf1 & \multirow{2}{*}{$\begin{array}{c}\text { Salvia fruticosa Mill. subsp. thomasii } \\
\text { (Lacaita) Brullo, Guglielmo, Pavone } \\
\text { \& Terrasi }\end{array}$} & $\begin{array}{l}\text { Gravina Petruscio } \\
\text { (Mottola, Taranto) }\end{array}$ & 11.03 .19 & $\begin{array}{l}40^{\circ} 36^{\prime} 34^{\prime \prime} \mathrm{N} \\
17^{\circ} 3^{\prime} 53.8^{\prime \prime} \mathrm{E}\end{array}$ \\
\hline Sf2 & & $\begin{array}{c}\text { Gaudella } \\
\text { (Laterza, Taranto) }\end{array}$ & 15.03 .19 & $\begin{array}{l}40^{\circ} 34^{\prime} 28.6^{\prime \prime} \mathrm{N} \\
16^{\circ} 50^{\prime} 59.6^{\prime \prime} \mathrm{E}\end{array}$ \\
\hline Sm1 & \multirow{2}{*}{ Satureja montana L. subsp. montana } & $\begin{array}{c}\text { Difesa di Malta } \\
\text { (Fasano, Brindisi) }\end{array}$ & 22.03 .19 & $\begin{array}{l}40^{\circ} 48^{\prime} 17.7^{\prime \prime} \mathrm{N} \\
17^{\circ} 29^{\prime} 53.2^{\prime \prime} \mathrm{E}\end{array}$ \\
\hline $\mathrm{Sm} 2$ & & $\begin{array}{l}\text { Monte Castiglione } \\
\text { (Altamura, Bari) }\end{array}$ & 01.04 .19 & $\begin{array}{l}40^{\circ} 52^{\prime} 33.2^{\prime \prime} \mathrm{N} \\
16^{\circ} 26^{\prime} 54.6^{\prime \prime} \mathrm{E}\end{array}$ \\
\hline $\mathrm{Tc} 1$ & \multirow{2}{*}{ Thymbra capitata (L.) Cav. } & $\begin{array}{l}\text { Gravina Capo di Gavito } \\
\text { (Mottola, Taranto) }\end{array}$ & 11.03 .19 & $\begin{array}{c}40^{\circ} 37^{\prime} 47^{\prime \prime} \mathrm{N} \\
17^{\circ} 4^{\prime} 5^{\prime \prime} \mathrm{E}\end{array}$ \\
\hline Tc2 & & $\begin{array}{l}\text { Torre Santa Sabina } \\
\text { (Carovigno, Brindisi) }\end{array}$ & 22.03 .19 & $\begin{array}{l}40^{\circ} 45^{\prime} 48.0^{\prime \prime} \mathrm{N} \\
17^{\circ} 41^{\prime} 19.6^{\prime \prime} \mathrm{E}\end{array}$ \\
\hline
\end{tabular}


Table 2. Acino suaveolentis-Stipetum austroitalicae Forte et Terzi in Forte, Perrino et Terzi 2005.

\begin{tabular}{|c|c|c|c|c|}
\hline Identificative Code & & Cs1 & Cs2 & Sm2 \\
\hline Altitude (m a. s.) & & 564 & 512 & 478 \\
\hline Aspect & & W-SW & SW & $\mathrm{E}$ \\
\hline Slope $\left(^{\circ}\right)$ & $u$ & 7 & 15 & 35 \\
\hline Relevé area $\left(\mathrm{m}^{2}\right)$ & $\bar{\Xi}$ & 50 & 60 & 40 \\
\hline Stoniness (\%) & 0 & 10 & 10 & 10 \\
\hline Rockiness (\%) & ت & 50 & 5 & 25 \\
\hline Cover total $(\%)$ & U & 70 & 85 & 80 \\
\hline Number of species & & 41 & 41 & 22 \\
\hline Number of individuals collected for laboratory analysis & & 150 & 120 & 50 \\
\hline Geolithological type & & $\S$ & $\S$ & $\S$ \\
\hline Ecopedologic type & & + & + & t+ \\
\hline Other species & & 18 & 18 & 3 \\
\hline
\end{tabular}

Characteristics association

Clinopodium suaveolens (Sm.) Kuntze

Thymus spinulosus Ten.

Euphorbia nicaeensis All. subsp. japygica (Ten.) Arcang.

\begin{tabular}{|c|c|c|c|c|}
\hline Clinopodium suaveolens (Sm.) Kuntze & & 3 & 3 & \\
\hline Thymus spinulosus Ten. & $\mathrm{E}$ & 2 & + & - \\
\hline Euphorbia nicaeensis All. subsp. japygica (Ten.) Arcang. & $\mathrm{E}$ & + & - & + \\
\hline Characteristics alliance Hyppocrepido glaucae-Stipion austroitalicae & & & & \\
\hline Stipa austroitalica Martinovský subsp. austroitalica & E & + & + & 3 \\
\hline Stachys germanica L. subsp. salviifolia (Ten.) Gams & & - & + & 1 \\
\hline Alyssum diffusum Ten. subsp. garganicum Španiel, Marhold, N.G.Passal. \& Lihová & E & + & - & - \\
\hline Linum tommasinii (Rchb.) Nyman & & + & - & - \\
\hline Petrorhagia saxifraga (L.) Link subsp. gasparrinii (Guss.) Greuter \& Burdet & & - & - & 1 \\
\hline
\end{tabular}

Characteristics order Scorzonero-Chrysopogonetalia

Teucrium capitatum L. subsp. capitatum

Satureja montana L. subsp. montana

Carex flacca Schreb. subsp. erythrostachys (Hoppe) Holub

Euphorbia myrsinites L. subsp. myrsinites

Anthyllis vulneraria L. subsp. rubriflora (DC.) Arcang.

Koeleria splendens C.Presl

Eryngium amethystinum L.

Characteristics order Brometalia erecti and Cl. Festuco-Brometea

Festuca circummediterranea Patzke

Anacamptis morio (L.) R.M.Bateman, Pridgeon \& M.W.Chase

Filipendula vulgaris Moench

Poterium sanguisorba $\mathrm{L}$.

Eryngium campestre $\mathrm{L}$.

Ophrys bombyliflora Link

Valeriana tuberosa L.

Ophrys funerea Viv.

Galium corrudifolium Vill.

\section{Characteristics/Transgressive class Lygeo sparti-Stipetea tenacissimae}

Asphodelus ramosus L. subsp. ramosus

Hyparrhenia hirta (L.) Stapf subsp. hirta

Charybdis pancration (Steinh.) Speta

Ferula communis L. subsp. communis

Reichardia picroides (L.) Roth

Clypeola jonthlaspi $\mathrm{L}$.

Petrosedum ochroleucum (Chaix) Niederle

Thapsia asclepium $\mathrm{L}$.

Poa bulbosa L. subsp. bulbosa

Helianthemum salicifolium (L.) Mill.

Hypochaeris achyrophorus L.

Plantago bellardii All. subsp. bellardii

Convolvulus elegantissimus Mill.

Valantia muralis L.

Brachypodium distachyon (L.) P.Beauv.

Dactylis glomerata L. subsp. hispanica (Roth) Nyman

Thapsia garganica L. subsp. garganica

Clypeola jonthlaspi $\mathrm{L}$.

Petrosedum ochroleucum (Chaix) Niederle

Thapsia asclepium $\mathrm{L}$.

$\begin{array}{llll}1 & + & + \\ 3 & - & 3 \\ + & + & - \\ + & + & - \\ + & - & - \\ + & - & - \\ & + & + & -\end{array}$

$\mathrm{E}=$ Endemic species

Geopedology: §, Skeletal limestones of neritic and carbonate platform facies (Upper Cretaceous); §§, Terrigenus-skeletal limestones like "Panchina" (Pleistocene); Ecopedology: †, Tyrrhenian carbonate reliefs with material defined by calcareous sedimentary rocks and climate from Oceanic to Suboceanic Mediterranean partially mountainous; $+\dagger$, Hilly reliefs with undifferentiated tertiary sedimentary rocks and sub-continental Mediterranean to continental Mediterranean climate. 
Table 3. Ruto chalepensis-Salvietum trilobae, Biondi \& Guerra 2008.

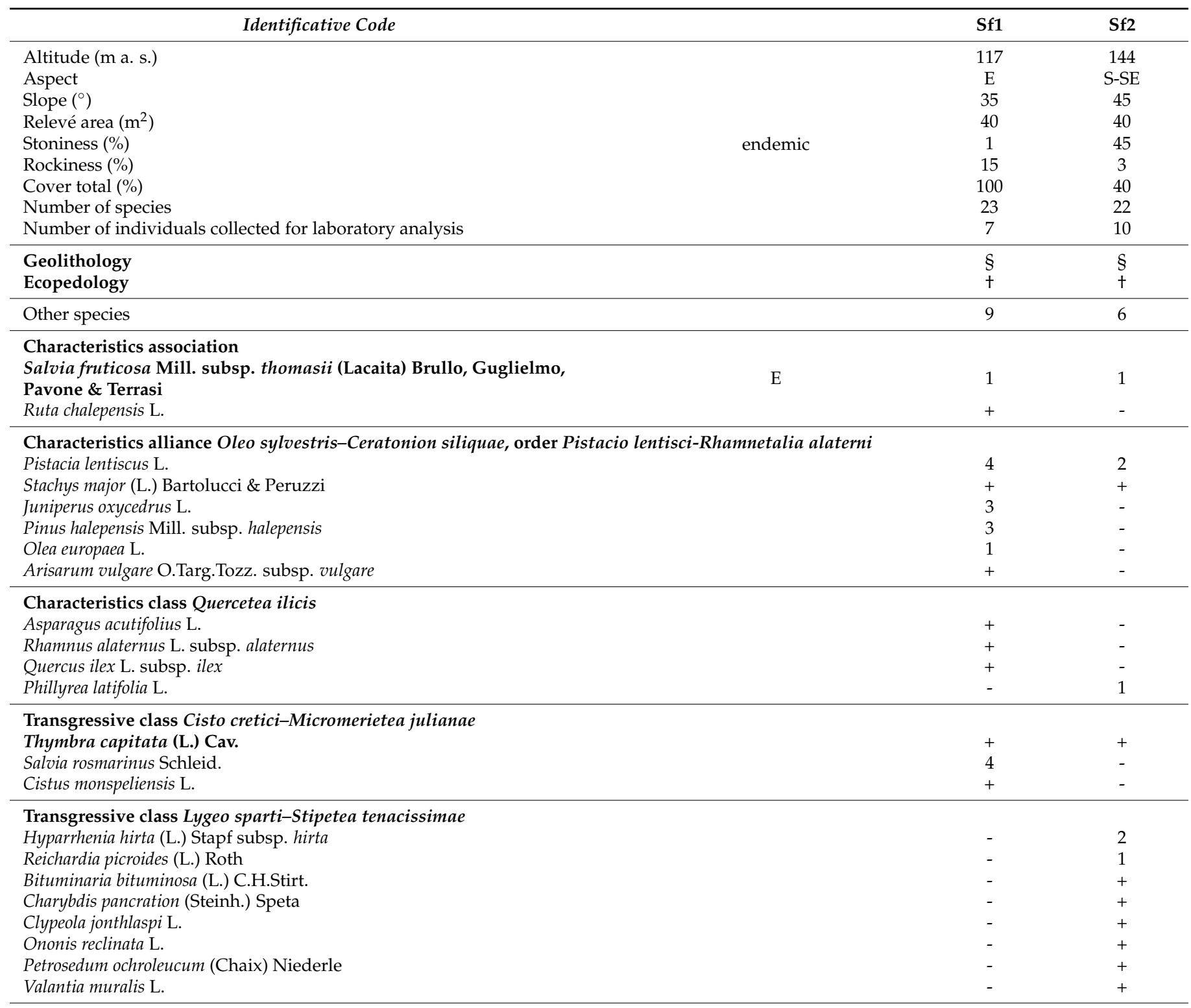

\section{$\mathrm{E}=$ Endemic species}

Geopedology

§: Skeletal limestones of neritic and carbonate platform facies (Upper

Cretaceous)

Ecopedology

t: Tyrrhenian carbonate reliefs with material defined by calcareous sedimentary rocks and climate from Oceanic to Suboceanic Mediterranean partially mountainous

Geopedology: §, Skeletal limestones of neritic and carbonate platform facies (Upper Cretaceous); Ecopedology: $\dagger$, Tyrrhenian carbonate reliefs with material defined by calcareous sedimentary rocks and climate from Oceanic to Suboceanic Mediterranean partially mountainous. 
Table 4. Asyneumo limonifolii-Saturejetum montanae, Biondi \& Guerra 2008.

\begin{tabular}{|c|c|c|c|c|}
\hline Identifacative Code & & Tc1 & Tc2 & Sm1 \\
\hline Altitude (m a. s.) & & 236 & 7 & 34 \\
\hline Aspect & & S-SE & NE & $\mathrm{E}$ \\
\hline Slope $\left({ }^{\circ}\right)$ & & 15 & 2 & 7 \\
\hline Relevé area $\left(\mathrm{m}^{2}\right)$ & & 45 & 50 & 20 \\
\hline Stoniness $(\%)$ & e $\mathrm{ndemic}$ & 10 & 10 & 5 \\
\hline Rockiness (\%) & & 2 & 2 & 5 \\
\hline Cover total $(\%)$ & & 95 & 100 & 70 \\
\hline Number of species & & 36 & 28 & 21 \\
\hline Number of individuals collected for laboratory analysis & & 30 & 50 & 40 \\
\hline Geolithology & & $\S$ & $\S \S$ & $\S \S$ \\
\hline Ecopedology & & $t$ & t+ & t+ \\
\hline Other species & & 13 & 6 & 10 \\
\hline
\end{tabular}

\section{Characteristics association}

Satureja montana L. subsp. montana

Characteristics/Transgressive Cisto cretici-Ericion manipuliflorae, order Cisto cretici-Ericetalia manipuliflorae, class Cisto cretici-Micromerietea julianae

Thymbra capitata (L.) Cav.

Teucrium capitatum L. subsp. capitatum

Micromeria graeca (L.) Benth. ex Rchb.

Cistus creticus L. subsp. eriocephalus (Viv.) Greuter \& Burdet

Lotus hirsutus L.

Phlomis fruticosa $\mathrm{L}$.

Cistus monspeliensis L.

Salvia rosmarinus Schleid.

Helianthemum jonium Lacaita \& Grosser

$\begin{array}{ccc}\text { cetici-Micromerietea julianae } & \\ 3 & 4 & + \\ + & + & 1 \\ + & + & + \\ + & 2 & - \\ + & 1 & - \\ 4 & - & - \\ - & 3 & - \\ - & + & - \\ - & - & 1\end{array}$

Characteristics/Transgressive class Lygeo sparti-Stipetea tenacissimae and Festuco-Brometea

Valantia muralis L.

Charybdis pancration (Steinh.) Speta

Reichardia picroides (L.) Roth

Scorzonera villosa Scop. subsp. columnae (Guss.) Nyman

Daucus carota L. subsp. carota

Hypochaeris achyrophorus L.

Clypeola jonthlaspi $\mathrm{L}$.

Festuca circummediterranea Patzke

Scorpiurus muricatus L.

Anthyllis vulneraria L. subsp. rubriflora (DC.) Arcang.

Convolvulus lineatus $\mathrm{L}$.

Carlina corymbosa L.

Daucus carota L. subsp. maritimus (Lam.) Batt.

Eryngium campestre L.

Transgressive class Stellarietea mediae

Urospermum picroides (L.) Scop. ex F.W.Schmidt

Calendula arvensis (Vaill.) L.

Erodium malacoides (L.) L'Hér. subsp. malacoides

Geranium molle L.

Stellaria media (L.) Vill. subsp. media

Vicia hybrida L.

Bellardia trixago (L.) All.

Vicia sativa L.

Transgressive class Quercetea ilicis

Stachys major (L.) Bartolucci \& Peruzzi

Olea europaea L.

Cytisus infestus (C.Presl) Guss. subsp. infestus

Pistacia lentiscus L.

Arisarum vulgare O.Targ.Tozz. subsp. vulgare

$\begin{array}{cccc} & + & 1 & 2 \\ & 2 & + & - \\ & + & + & - \\ & + & + & - \\ + & - & - \\ 1 & - & - \\ & + & - & - \\ & + & - & - \\ & + & 1 & - \\ & - & 1 & - \\ & - & + & -\end{array}$

Transgressive class Tuberarietea guttatae

Brachypodium distachyon (L.) P.Beauv.

$\mathrm{E}=$ Endemic species

Geopedology

$\S$, Skeletal limestones of neritic and carbonate platform facies (Upper Cretaceous)

$\S \S$, Terrigenus-skeletal limestones like "Panchina" (Pleistocene)

Ecopedology

$t$, Tyrrhenian carbonate reliefs with material defined by calcareous sedimentary rocks and climate from Oceanic to Suboceanic Mediterranean partially mountainous

t+, Hilly reliefs with undifferentiated tertiary sedimentary rocks and sub-continental Mediterranean to continental Mediterranean climate

E = Endemic species; Geopedology: §, Skeletal limestones of neritic and carbonate platform facies (Upper Cretaceous); $\S \S$, Terrigenusskeletal limestones like "Panchina" (Pleistocene); Ecopedology: $\dagger$, Tyrrhenian carbonate reliefs with material defined by calcareous sedimentary rocks and climate from Oceanic to Suboceanic Mediterranean partially mountainous; ++ , Hilly reliefs with undifferentiated tertiary sedimentary rocks and sub-continental Mediterranean to continental Mediterranean climate.

The identification of the taxa was carried out according to Flora d'Italia [21] and Flora Europea [22], with nomenclature standardized by "An updated checklist of the vascular flora native to Italy" [23] and "An updated checklist of the vascular flora alien to Italy" [24], 
while the syntaxonomic framework was conceived by several contributions [25-27], reported in the phytosociological tables and summarized in the syntaxonomic scheme.

The aerial parts of the studied plant species were harvested on the same sites and dates as the vegetation surveys. The number of individuals collected (from 7 to 150) for the laboratory analysis are reported in the phytosociological tables (Tables 2-4).

\subsection{Laboratory Analysis}

The essential oils (EOs) of the selected wild plant species were extracted by hydrodistillation [28] using a Clevenger type apparatus for $4-5 \mathrm{~h}$. Air dried plant material (100 g) was added to $500 \mathrm{~mL}$ distilled water in a $1 \mathrm{~L}$ volume distillation flask (extraction ratio $1: 5 \mathrm{w} / \mathrm{vol})$. EOs were collected in amber glass vials, weighted, and stored at $4{ }^{\circ} \mathrm{C}$. The EOs yield $(\% w / w)$ were determined as grams of EOs per $100 \mathrm{~g}$ of dry weight plant material.

The identification of compounds present in the EOs extracts was done by Gas Chromatography coupled with Mass Spectrometry (GC-MS) using a Clarus 680 GC equipped with an Elite-5 MS fused silica capillary column $(30 \mathrm{~m} \times 0.25 \mathrm{~mm}$ and $0.25 \mu \mathrm{M}$ film thickness) and interfaced with a single quadrupole mass spectrometer Clarus SQ8C (Perkin Elmer). Mass spectra of target compounds were obtained by an electron impact ionization system with standardized ionization energy of $70 \mathrm{eV}$. Helium 5.5 was used as a carrier gas at a constant flow rate of $1 \mathrm{~mL} / \mathrm{min}$. Mass transfer line and injector temperatures were set at $280{ }^{\circ} \mathrm{C}$ and the oven temperature was programmed from $50{ }^{\circ} \mathrm{C}$ to $160{ }^{\circ} \mathrm{C}$ at $5{ }^{\circ} \mathrm{C} / \mathrm{min}$, then raised to $250{ }^{\circ} \mathrm{C}$ at $10{ }^{\circ} \mathrm{C} / \mathrm{min}$, held at the final temperature for $5 \mathrm{~min}$. Diluted samples (1:10, $v / v$, in hexane) were injected in split mode with a split ratio of 1:100. Data were collected in full scan mode in the range 40-300 amu (atomic mass unit). A solvent delay of 4 min was applied. Qualitative results include compound identification and area percentage of related peak in the total ions chromatogram (Table 5).

Table 5. Chemical composition (\%) of Salvia fruticosa subsp. thomasii (Sf), Thymbra capitata (Tc), Satureja montana subsp. montana (Sm), Clinopodium suaveolens (Cs).

\begin{tabular}{|c|c|c|c|c|c|c|c|c|}
\hline Compound Name & Sf1 & Sf2 & Cs1 & Cs2 & Tc1 & Tc2 & Sm1 & Sm2 \\
\hline Methyl 3(Z)-Hexenyl Ether & 0.03 & & & & & & & \\
\hline Salvene, cis- & 0.06 & 0.09 & & & & & & \\
\hline 3-Hexen-1-ol, trans- & 0.05 & & & & 0.10 & 0.11 & 0.07 & 0.08 \\
\hline trans-Salvene & 0.01 & 0.01 & & & & & & \\
\hline 2-Hexen-1-ol, trans- & 0.01 & & & & & & & \\
\hline 1-Hexanol & 0.02 & 0.01 & & & & & & \\
\hline 2- $\alpha$-Pinene & 0.11 & 0.16 & & & & & & \\
\hline Tricyclene & 0.24 & 0.01 & & & 0.01 & 0.02 & 0.11 & 1.15 \\
\hline$\alpha$-Thujene & 0.39 & 0.25 & 0.03 & 0.06 & 1.89 & 1.50 & & \\
\hline$\alpha$-Pinene, (-)- & 5.05 & 3.58 & 0.51 & 0.63 & 0.94 & 0.69 & 26.96 & 0.69 \\
\hline 2,4(10)-thujadien & 0.03 & 0.01 & & & 0.02 & 0.01 & 0.01 & 0.02 \\
\hline Camphene & 6.32 & 0.51 & 0.08 & 0.10 & 0.27 & 0.30 & 0.51 & 0.18 \\
\hline Verbenene & 0.02 & 0.01 & & & & & 0.21 & \\
\hline Sabinene & & & 0.15 & 0.21 & 0.08 & 0.10 & 1.02 & 0.09 \\
\hline$\beta$-Pinene & 0.37 & 0.20 & 0.65 & 0.72 & 0.39 & 0.25 & 0.74 & 0.62 \\
\hline 1-Octen-3-ol & 0.04 & 0.10 & & & 0.01 & 0.01 & 0.02 & 0.01 \\
\hline 3-Octanone & & & 0.01 & 0.01 & & & & \\
\hline$\beta$-Mircene & 2.70 & 3.90 & 0.33 & 0.39 & 1.92 & 1.51 & 2.85 & 1.67 \\
\hline 3-Octanol & & & 0.10 & 0.08 & 0.04 & 0.07 & 0.04 & 0.02 \\
\hline Pseudolimonene & 0.03 & 0.02 & 0.03 & 0.04 & & & & \\
\hline$\alpha$-Phellandrene & 0.05 & 0.04 & & & 0.34 & 0.29 & 0.88 & 0.27 \\
\hline 8-3-Carene & & & & & 0.16 & 0.08 & 0.01 & 0.06 \\
\hline$\alpha$-Terpinene & 0.40 & 0.30 & 0.01 & 0.02 & 2.54 & 2.81 & 0.11 & 2.82 \\
\hline p-Cymene & 1.17 & 0.87 & 0.04 & 0.06 & 9.25 & 9.67 & 0.41 & 10.43 \\
\hline dl-Limonene & 1.41 & 0.84 & 3.35 & 2.37 & 0.72 & 0.59 & 7.05 & 0.61 \\
\hline Eucalyptol & 40.22 & 60.94 & 0.07 & 0.08 & 0.01 & 0.01 & & \\
\hline$\beta$-Ocimene, trans- & 0.01 & 0.02 & 0.02 & 0.02 & 0.01 & 0.01 & 11.45 & 1.98 \\
\hline$\beta$-Ocimene, cis- & 0.67 & 0.53 & 0.02 & 0.03 & 0.07 & 0.06 & 5.05 & 0.58 \\
\hline$\gamma$-Terpinene & & & & & 14.95 & 17.71 & 0.18 & 14.57 \\
\hline
\end{tabular}


Table 5. Cont.

\begin{tabular}{|c|c|c|c|c|c|c|c|c|}
\hline Compound Name & Sf1 & Sf2 & Cs1 & Cs2 & Tc1 & Tc2 & Sm1 & $\operatorname{Sm} 2$ \\
\hline Sabinene hydrate, cis- & & & & & 0.06 & 0.06 & 0.08 & 0.09 \\
\hline Terpinolene & 0.16 & 0.11 & 0.02 & 0.03 & 0.14 & 0.10 & 0.26 & 0.10 \\
\hline p-Cymenene & 0.04 & 0.03 & & & 0.03 & 0.04 & 0.11 & 0.03 \\
\hline Linalool & 0.13 & 0.15 & 0.48 & 0.25 & 1.25 & 2.38 & 7.37 & 1.19 \\
\hline Thujone, cis- & 4.26 & 4.89 & 0.02 & 0.01 & 0.03 & & 0.11 & \\
\hline Thujone, trans- & 1.71 & 1.29 & & & 0.02 & 0.02 & & \\
\hline Chrysanthenone & & & & & 0.06 & 0.05 & 0.03 & 0.03 \\
\hline$\alpha$-Campholenal & & & & & & & 0.19 & 0.01 \\
\hline trans-Pinocarveol & 0.21 & 0.12 & & & & & & \\
\hline Sabinol, cis- & & & & & & & 0.35 & 0.05 \\
\hline Verbenol, cis- & & & & & & & 0.76 & 0.03 \\
\hline Camphor & 14.88 & 1.89 & & & & & & \\
\hline trans-3-Caren-2-ol & & & & & & & 0.16 & 0.01 \\
\hline Menthone & & & 0.38 & 0.56 & & & & \\
\hline Pinocarvone & & & & & & & 0.10 & 0.01 \\
\hline$\delta$-Terpineol & 0.76 & 0.81 & 12.22 & 17.20 & & & & \\
\hline Borneol & 1.59 & & & & 0.60 & 0.74 & 1.20 & 0.35 \\
\hline Isopulegone & & & 1.51 & 1.65 & & & & \\
\hline Terpinene-4-ol & 1.33 & 0.73 & 0.08 & 0.08 & 1.17 & 0.95 & 0.37 & 0.86 \\
\hline p-Cymen-8-ol & & & & & 0.03 & 0.06 & 0.17 & 0.10 \\
\hline Hexyl butanoate & & & & & 0.04 & 0.03 & & \\
\hline$\alpha$-Terpineol & 2.61 & 2.71 & 0.08 & 0.06 & 0.14 & 0.11 & 14.92 & 0.29 \\
\hline Decanal & & & 0.03 & 0.03 & 0.02 & 0.01 & & \\
\hline Verbenone & & & 0.04 & 0.03 & 0.01 & 0.01 & 0.15 & 0.01 \\
\hline Carveol, trans- & & & & & & & 0.11 & 0.01 \\
\hline Nerol & 0.05 & 0.01 & & & 0.04 & 0.03 & & \\
\hline Thymol, methyl ether & & & & & & & 0.01 & 1.65 \\
\hline Carvacrol, methyl ether & & & & & & & 0.01 & 3.87 \\
\hline Pulegone & & & 79.48 & 75.1 & & & & \\
\hline Cumin aldehyde & & & & & & & 0.08 & 0.02 \\
\hline Z-Citral & 0.04 & & & & & & & \\
\hline Bornyl acetate & 0.06 & & & & & & 0.09 & \\
\hline Thymol & 0.02 & 0.52 & & & 31.12 & 35.66 & 0.11 & 46.10 \\
\hline Carvacrol & 0.02 & 0.24 & & & 26.01 & 17.44 & 0.10 & 2.17 \\
\hline Piperitenone & & & 0.13 & 0.11 & & & & \\
\hline thymol acetate & 0.45 & 0.13 & & & 0.35 & 0.77 & & 0.55 \\
\hline Carvacrol acetate & & & & & 0.26 & 0.41 & & \\
\hline$\alpha$-Copaene & & & & & & & 0.69 & 0.04 \\
\hline$\beta$-Elemene & & & & & & & 0.04 & 0.02 \\
\hline$\alpha$-Gurjunene & & & & & 0.04 & 0.02 & 0.06 & 0.10 \\
\hline Caryophyllene, trans- & 1.78 & 1.72 & 0.06 & 0.04 & 2.42 & 2.29 & 0.31 & 0.90 \\
\hline$\alpha$-Bergamotene, trans- & & & & & 0.02 & 0.02 & 0.11 & 0.04 \\
\hline Aromadendrene & 0.25 & 0.22 & & & 0.04 & 0.03 & 0.58 & 0.03 \\
\hline$\alpha$-Humulene & 0.57 & 0.66 & & & 0.03 & 0.01 & 0.10 & 0.03 \\
\hline$\beta$-Santalene & & & & & 0.08 & 0.07 & 0.02 & 0.03 \\
\hline Alloaromadendrene & & & & & 0.04 & 0.02 & 0.04 & 0.01 \\
\hline Germacrene D & & & 0.08 & 0.06 & & & 0.31 & 0.59 \\
\hline Guaia-1(10),11-diene & 0.08 & 0.06 & & & 0.04 & 0.03 & 0.07 & 0.02 \\
\hline$\beta$-Guaiene, trans- & 0.10 & 0.04 & & & 0.19 & 0.29 & 1.85 & 0.09 \\
\hline$\beta$-Bisabolene & & & & & 0.29 & 0.28 & & 3.53 \\
\hline$\beta$-Curcumene & & & & & & & 0.63 & \\
\hline$\alpha$-Muurolene & 0.05 & 0.04 & & & & & 0.07 & 0.04 \\
\hline Calamenene, cis- & 0.11 & 0.10 & & & 0.03 & 0.04 & 0.08 & 0.04 \\
\hline Sesquiphellandrene & & & & & & & 0.03 & 0.04 \\
\hline$\alpha$-Bisabolene, $(\mathrm{E})-$ & & & & & 0.22 & 0.24 & & 0.10 \\
\hline Sesquisabinene hydrate, cis- & & & & & & & 2.79 & 0.06 \\
\hline trans-Sesquisabinene hydrate & & & & & & & 0.15 & 0.01 \\
\hline (-)-Spathulenol & & & & & & & 0.61 & 0.03 \\
\hline
\end{tabular}


Compounds identification was performed by both Retention Indexes (RI) $[29,30]$ and mass spectra (MS) search in NIST and Wiley databases (Table 6).

Table 6. List of the identified compounds in the essential oils extracts and the identification method (IM) used: MS: Mass Spectrum search against Nist and Wiley database; RI: experimental and theoretical Retention Index comparison; RI ref: Retention Index reference; RT: Retention Time.

\begin{tabular}{|c|c|c|c|c|}
\hline Compound Name & RT & RI & RI Ref & IM \\
\hline Methyl 3(Z)-Hexenyl Ether & 4.341 & 823 & & MS \\
\hline cis-Salvene & 4.783 & 845 & & MS \\
\hline 3-Hexen-1-ol, trans- & 4.833 & 847 & 856 & MS/RI \\
\hline trans-Salvene & 4.971 & 854 & & MS \\
\hline 2-Hexen-1-ol, trans- & 5.033 & 857 & & MS \\
\hline 1-Hexanol & 5.112 & 861 & 870 & $\mathrm{MS} / \mathrm{RI}$ \\
\hline 2- $\alpha$-Pinene & 6.363 & 918 & & MS \\
\hline Tricyclene & 6.421 & 923 & 923 & $\mathrm{MS} / \mathrm{RI}$ \\
\hline$\alpha$-Thujene & 6.492 & 925 & 927 & $\mathrm{MS} / \mathrm{RI}$ \\
\hline$\alpha$-Pinene, (-)- & 6.692 & 933 & 936 & MS/RI \\
\hline 2,4(10)-thujadien & 6.938 & 943 & 943 & MS/RI \\
\hline Camphene & 7.117 & 950 & 950 & MS/RI \\
\hline verbenene & 7.209 & 951 & 963 & MS/RI \\
\hline Sabinene & 7.755 & 972 & 973 & MS/RI \\
\hline$\beta$-Pinene & 7.897 & 977 & 977 & MS/RI \\
\hline 1-Octen-3-ol & 7.98 & 980 & 980 & MS/RI \\
\hline 3-Octanone & 8.039 & 983 & 984 & $\mathrm{MS} / \mathrm{RI}$ \\
\hline$\beta$-Mircene & 8.118 & 988 & 989 & MS/RI \\
\hline 3-Octanol & 8.351 & 995 & 993 & MS/RI \\
\hline Pseudolimonene & 8.539 & 1002 & 992 & MS/RI \\
\hline$\alpha$-Phellandrene & 8.597 & 1004 & 1004 & MS/RI \\
\hline$\delta$-3-Carene & 8.743 & 1009 & 1005 & MS/RI \\
\hline$\alpha$-Terpinene & 8.898 & 1017 & 1017 & MS/RI \\
\hline p-Cymene & 9.102 & 1024 & 1024 & MS/RI \\
\hline dl-Limonene & 9.252 & 1029 & 1029 & MS/RI \\
\hline Eucalyptol & 9.348 & 1032 & 1032 & MS/RI \\
\hline$\beta$-Ocimene, trans- & 9.698 & 1035 & 1035 & MS/RI \\
\hline$\beta$-Ocimene, cis- & 9.769 & 1044 & 1041 & MS/RI \\
\hline$\gamma$-Terpinene & 10.052 & 1058 & 1060 & MS/RI \\
\hline Sabinene hydrate, cis- & 10.448 & 1069 & 1066 & MS/RI \\
\hline Terpinolene & 10.832 & 1085 & 1087 & MS/RI \\
\hline p-Cymenene & 10.944 & 1087 & 1088 & MS/RI \\
\hline Linalool & 11.195 & 1098 & 1099 & MS/RI \\
\hline Thujone, cis- & 11.42 & 1104 & 1105 & MS/RI \\
\hline Thujone, trans- & 11.741 & 1116 & 1115 & MS/RI \\
\hline Chrysanthenone & 11.991 & 1124 & 1124 & MS/RI \\
\hline$\alpha$-Campholenal & 12.016 & 1125 & 1124 & MS/RI \\
\hline trans-Pinocarveol & 12.416 & 1140 & 1140 & MS/RI \\
\hline Sabinol, cis- & 12.454 & 1142 & 1142 & MS/RI \\
\hline Verbenol, cis & 12.558 & 1144 & 1144 & MS/RI \\
\hline Camphor & 12.595 & 1146 & 1143 & MS/RI \\
\hline trans-3-Caren-2-ol & 12.695 & 1149 & & MS \\
\hline Menthone & 12.87 & 1155 & 1150 & MS/RI \\
\hline Pinocarvone & 13.037 & 1161 & 1161 & $\mathrm{MS} / \mathrm{RI}$ \\
\hline$\delta$-Terpineol & 13.221 & 1165 & 1165 & MS/RI \\
\hline Borneol & 13.287 & 1170 & 1166 & MS/RI \\
\hline Isopulegone & 13.417 & 1175 & 1176 & MS/RI \\
\hline Terpinene-4-ol & 13.529 & 1178 & 1177 & MS/RI \\
\hline p-Cymen-8-ol & 13.733 & 1181 & 1184 & MS/RI \\
\hline Hexyl butanoate & 13.867 & 1191 & 1191 & MS/RI \\
\hline$\alpha$-Terpineol & 13.925 & 1195 & 1190 & MS/RI \\
\hline Decanal & 14.25 & 1204 & 1200 & MS/RI \\
\hline Verbenone & 14.346 & 1208 & 1206 & MS/RI \\
\hline
\end{tabular}


Table 6. Cont.

\begin{tabular}{|c|c|c|c|c|}
\hline Compound Name & RT & RI & RI Ref & IM \\
\hline Carveol, trans- & 14.605 & 1215 & 1217 & MS/RI \\
\hline Nerol & 14.717 & 1221 & 1229 & $\mathrm{MS} / \mathrm{RI}$ \\
\hline Thymol, methyl ether & 14.901 & 1231 & 1234 & MS/RI \\
\hline Carvacrol, methyl ether & 15.113 & 1236 & 1243 & MS/RI \\
\hline Pulegone & 15.251 & 1239 & 1237 & MS/RI \\
\hline Cumin aldehyde & 15.288 & 1242 & 1238 & MS/RI \\
\hline Z-Citral & 15.893 & 1264 & & MS \\
\hline Bornyl acetate & 16.389 & 1283 & 1283 & MS/RI \\
\hline Thymol & 16.535 & 1290 & 1290 & MS/RI \\
\hline Carvacrol & 16.718 & 1299 & 1300 & MS/RI \\
\hline Piperitenone & 17.844 & 1337 & 1340 & $\mathrm{MS} / \mathrm{RI}$ \\
\hline thymol acetate & 18.027 & 1345 & 1354 & MS/RI \\
\hline Carvacrol acetate & 18.519 & 1363 & 1356 & MS/RI \\
\hline$\alpha$-Copaene & 18.823 & 1378 & 1376 & MS/RI \\
\hline$\beta$-Elemene & 19.207 & 1391 & 1390 & MS/RI \\
\hline$\alpha$-Gurjunene & 19.695 & 1409 & 1408 & MS/RI \\
\hline Caryophyllene, (E)- & 19.982 & 1421 & 1420 & MS/RI \\
\hline$\alpha$-Bergamotene, trans- & 20.328 & 1423 & 1434 & MS/RI \\
\hline Aromadendrene & 20.453 & 1440 & 1441 & MS/RI \\
\hline$\alpha$-Humulene & 20.874 & 1452 & 1453 & $\mathrm{MS} / \mathrm{RI}$ \\
\hline$\beta$-Santalene & 20.916 & 1458 & 1458 & MS/RI \\
\hline Alloaromadendrene & 21.029 & 1463 & 1460 & MS/RI \\
\hline Germacrene D isomer & 21.387 & 1477 & & MS \\
\hline Germacrene D & 21.521 & 1483 & 1481 & MS/RI \\
\hline Guaia-1(10),11-diene & 21.746 & 1492 & & MS \\
\hline$\beta$-Guaiene, trans- & 21.871 & 1498 & 1499 & MS/RI \\
\hline$\beta$-Bisabolene & 22.142 & 1509 & 1508 & MS/RI \\
\hline$\beta$-Curcumene & 22.158 & 1510 & 1513 & MS/RI \\
\hline$\alpha$-Muurolene & 22.254 & 1514 & 1498 & MS/RI \\
\hline Calamenene, cis- & 22.421 & 1522 & 1522 & MS/RI \\
\hline Sesquiphellandrene & 22.5 & 1525 & 1523 & MS/RI \\
\hline$\alpha$-Bisabolene, $(\mathrm{E})-$ & 22.9 & 1543 & 1540 & MS/RI \\
\hline Sesquisabinene hydrate, cis- & 22.955 & 1546 & 1541 & MS/RI \\
\hline Sesquisabinene hydrate, trans- & 23.201 & 1557 & & MS \\
\hline Caryophyllene oxide & 23.313 & 1562 & 1580 & MS/RI \\
\hline (-)-Spathulenol & 23.743 & 1581 & 1576 & MS/RI \\
\hline Aromadendrene oxide- & 23.847 & 1585 & & MS \\
\hline a-Humulene oxide & 24.097 & 1596 & 1601 & MS/RI \\
\hline
\end{tabular}

The chemical composition (\%) of relative compounds of Clinopodium suaveolens, Salvia fruticosa subsp. thomasii, Satureja montana subsp. montana, and Thymbra capitata is reported in Table 5. Statistical analysis was not applicable due to the low number of samples per species and site, limited amount of material per sample, and few and variable number of individuals per specimen (7-150), due in part also to the fact that the study was pursued on at least two species of conservation interest.

\section{Results and Discussions}

\subsection{Clinopodium suaveolens (Sm.) Kuntze}

C. suaveolens (synonyms: Acinos heterophyllus G. Don, Acinos suaveolens (Sm.) Loudon, Calamintha acinoides (Ten.) Nyman, Calamintha acuminata Friv., Calamintha langei Nyman, Calamintha patavina Heldr. ex Nyman, Melissa acinoides (Ten.) Nyman, Melissa suaveolens (Sm.) Nyman, Satureja suaveolens (Sm.) Watzl, Thymus acinoides Ten., Thymus melissoides Bernh. ex Rchb., Thymus melissoides Schweigg., Thymus suaveolens Sm.) (Figure 2). 


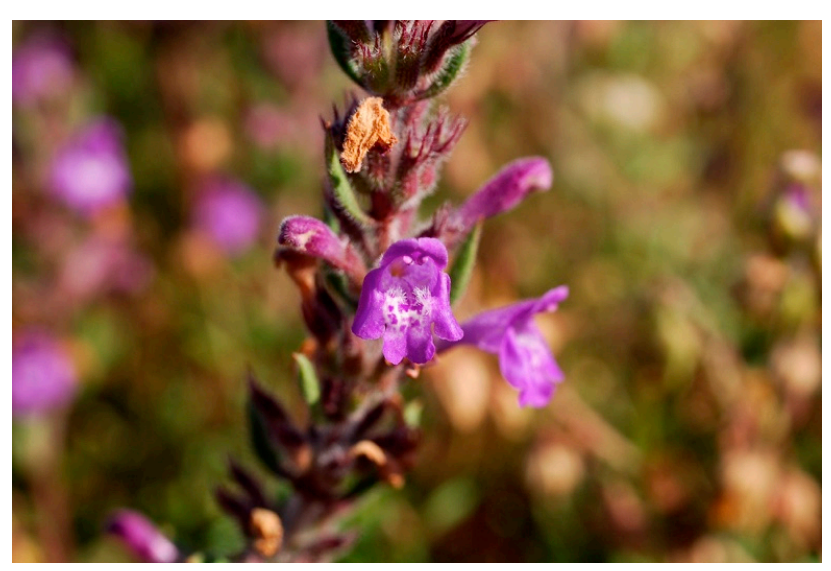

(a)

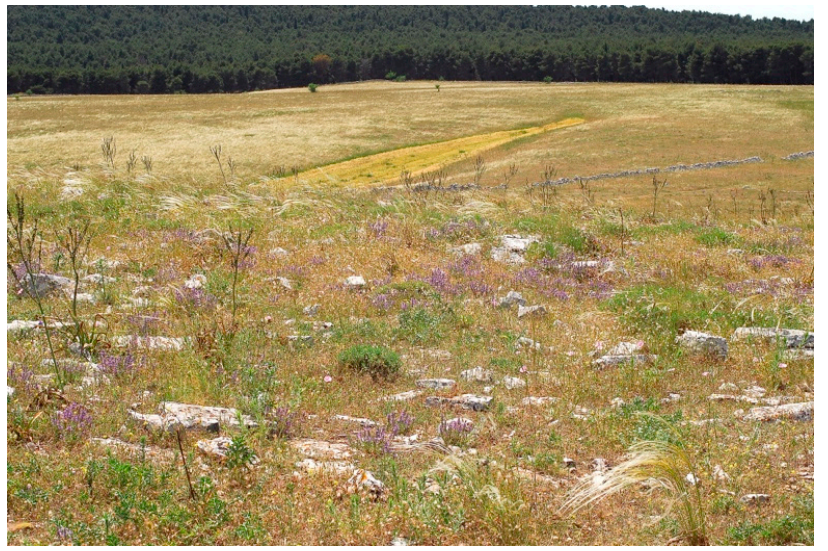

(b)

Figure 2. Clinopodium suaveolens (Sm.) Kuntze: (a) in flowering; (b) in its habitat, Acinos suaveolentis-Stipetum austroitalicae association.

Recently, some Satureja L., Micromeria Bentham, section Pseudomelissa Bentham species and all species of Calamintha Miller and Acinos Miller were transferred to Clinopodium by several authors [31-36]. Thus, the number of species belonging to the genus Clinopodium has reached about 100. They are mostly distributed in the New World (both temperate and tropical) and temperate Eurasia, but there are a few in Africa, tropical Asia, and Indo-Malaysia [37].

C. suaveolens is a Mediterranean species with a north-eastern distribution, reported in Italy, former Yugoslavia, Albania, Greece, Bulgaria, and Turkey [38]. In Italy, it occurs in four Italian regions: Abruzzo, Campania, Apulia, and Basilicata [23], and it is a species of conservation interest cited in the Regional Red List with the status of Vulnerable (VU) for Apulia [39]. It grows with high coverage in the "Alta Murgia" interland (Central part of the Apulia region) in the grassland community of Acinos suaveolentis-Stipetum austroitalicae [10,40,41], which is a protected habitat by Directive 92/43 EEC (Eastern sub-Mediterranean dry grasslands (Scorzoneretalia villosae) (Code 62A0)). Outside of the Murgian territory, C. suaveolens is a typical species of the chamephytic or nanophanerophytic plant communities [42] habitually referred to the Sarcopoterietalia spinosi Br.-Bl. 1933 nom. mut. propos Rivas-Martínez, T.E. Díaz, Fernandez-Gonzales, Izco, Loidi, Lousã \& Penas 2002 order $[43,44]$.

The data collected about $C$. suaveolens, due to its limited regional distribution and peculiar ecology, as it is one of the characteristic species that gave its name to the Acinos suaveolentis-Stipetum austroitalicae endemic association of Alta Murgia (North-West of Apulia), show that it does not grow outside of the just mentioned plant community, with which it shares the same geolithological and ecopedologic context. Consequently, the two detected vegetations are comparable (Table 2).

In the typical context of the Acinos suaveolentis-Stipetum austroitalicae community at Scannapecora (Cs1), with five endemic species (Thymus spinulosus, Euphorbia nicaeensis subsp. japygica, Stipa austroitalica subsp. austroitalica, Alyssum diffusum subsp. garganicum, Koeleria splendens), a high percentage of rockiness (50\%), on a slope with $7^{\circ}$ of aspect exposed to W-SW, the GC/MS results show the presence of 4 main compounds out of a total of 29 in the EOs. The most abundant component is pulegone with about $80 \%$ of the total area, followed by $\delta$-terpineo, D-limonene, and isopulegone (Table 5).

In a more disturbed aspect of the same community at Jazzo Filieri (Cs2), due to an overgrazing explained by the presence of a greater number of species of Lygeo sparti-Stipetea tenacissimae, and in particular, a high coverage of Asphodelus ramosus L. subsp. ramosus, plant not eaten by cattle, less percentage of rockiness (5\%), and endemics species, on a slope with $15^{\circ}$ of aspect exposed to SW, the EOs composition shows the same composition of Cs1. 
The two populations (Cs1 and Cs2) are different in terms of EOs composition percentage, since they show the same compounds but present with different abundance (Table 5). The EOs yield mean for this species was $0.39 \%$ with a higher value in Cs2 $(+12 \%$ of the mean value, $p<0.05)$ in respect to Cs1. Pulegone is the most abundant component in both populations, higher in Cs1 (79.5\%) than in Cs2 (75.1\%), and therefore the two populations belong to the same pulegone chemotype. One could speculate that at the Jazzo Filieri site (Cs2), the $\delta$-terpineol is the compound that took the place of pulegone at Scannapecora (Cs1) with a $5 \%$ increase (from $12.4 \%$ to $17.4 \%$ ), proving to be more suitable for more stressed environments. It is possible to state that this species is partially susceptible to microclimatic, topography, and vegetation changes, which affect the type of EOs, even in close geographycal sites or stations.

It is noteworthy to know that $C$. suaveolens differs from other related Clinopodium species as it is strongly odorous, and therefore richer in EOs. Data about EOs of C. suaveolens are rather scanty $[45,46]$, due mainly to the natural rarity of the species, though they indicate richness in pulegone as the main phytochemical. Pulegone is a monoterpene ketone [47] often present in the leaf and flower tops of the Mentha L. genus. Plant species containing pulegone are used in traditional remedies, flavouring, spices and as an insect repellent $[48,49]$. They are widely used in Turkey (Balıkesir province) as tea [45], and in Greece as decoction, due to their sedative, diuretic and anti-inflammatory properties [50]. Moreover, the compound exhibits other different biological and pharmacological activities [51], which make it also potentially suitable for an industrial use.

\subsection{Salvia Fruticosa Mill. subsp. thomasii (Lacaita) Brullo Guglielmo, Pavone E Terrasi}

Salvia fruticosa subsp. thomasii (synonym: Salvia thomasii Lacaita, S. triloba L.) is one of 1000 species belonging to the Salvia L. genus [52]. This perennial shrub is an endemic species located in some regions of the center-south of Italy [23]. In Apulia, the species has been detected in the central-eastern area of the "Gravine Arco Jonico" (Taranto), near Masseria Gaudella (Laterza) and in Gravina del Petruscio (Mottola). Other authors [18,53] observed that Gravina del Petruscio was the richest in individuals and presented a good capacity for renewal, while the population of a few individuals in Masseria Gaudella did not show a similar capacity. In all cases, there are doubts about the ability of this taxon to complete fruit ripening. The only available data are those related to the nominal species, whereas no scientific data related to the specific subspecies exist (Figure 3).

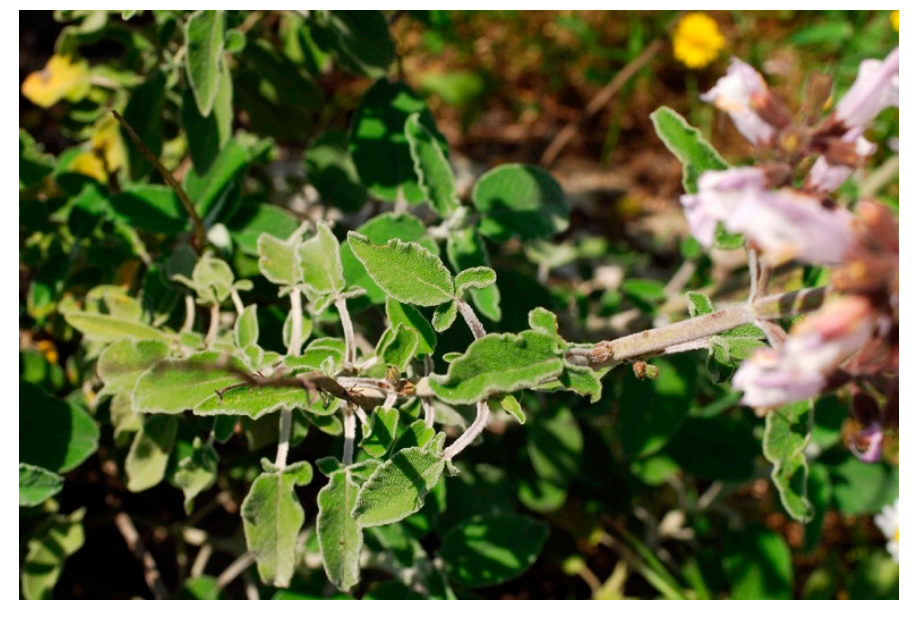

(a)

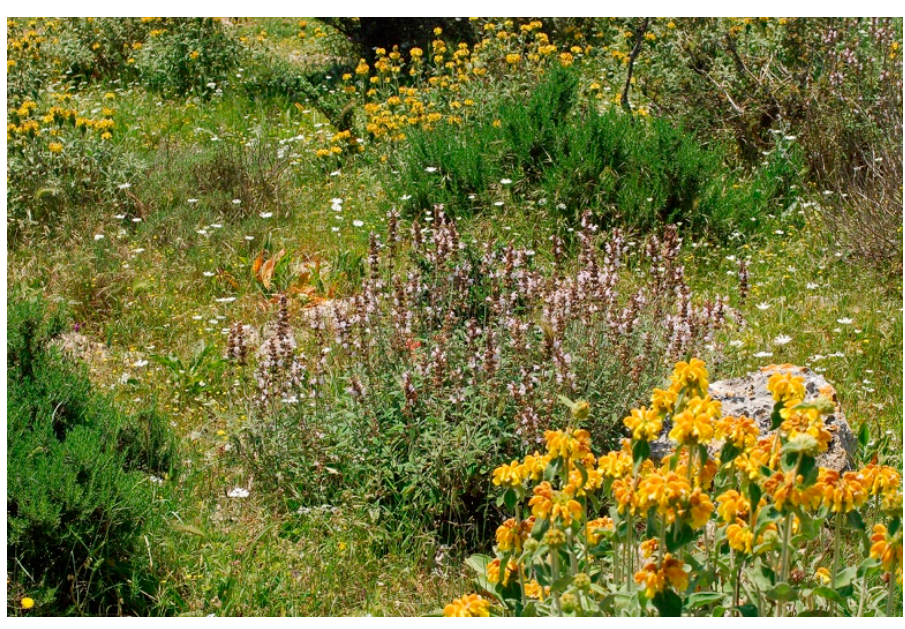

(b)

Figure 3. Salvia fruticosa Mill. subsp. thomasii (Lacaita) Brullo, Guglielmo, Pavone \& Terrasi: (a) trilobe leaves; (b) in its habitat, Ruto chalepensis-Salvietum trilobae, Biondi \& Guerra 2008.

The vegetation of this endemic taxon was detected in Gravina Petruscio (Sf1) and near Gaudella (Sf2) in the province of Taranto. The phytosociological data of both sites 
(Table 3) only seemingly show comparable topographic conditions within the same plant association Ruta chalepensis-Salvietum trilobae, but a careful reading reveals microstational differences of an environmental nature as well as in terms of plant communities, which reflected in the quantity and types of EOs. At Gravina Petruscio in a good environmental condition, in the absence of human disturbances, with $117 \mathrm{~m}$ altitude, $35^{\circ}$ slope, a low level of stoniness $(1 \%)$, and a moderate level of rockiness $(15 \%)$, and $100 \%$ coverage of 23 plant species, we observed a richness species of Oleo sylvestris-Ceratonion siliquae and Pistacio lentisci-Rhamnetalia alaterni communities as Pistacia lentiscus, Stachys major, Juniperus oxycedrus, Pinus halepensis subsp. halepensis, Olea europaea and Arisarum vulgare subsp. vulgare, as well as Salvia fruticosa subsp. thomasii and Ruta chalepensis, diagnostic species of Ruto chalepensis-Salvietum trilobae association. Some transgressive species of Cisto creticiMicromerietea julianae class, and in particular, Salvia rosmarinus, show the natural catenal contact with the two communities.

In less natural condition, with $144 \mathrm{~m}$ altitude, greater slope degree $\left(45^{\circ}\right)$, a high level of stoniness $(45 \%)$ with a low level of rockiness (3\%), and medium coverage $(40 \%)$ of 22 plant species detected, we observed a mosaic community between Ruto chalepensis-Salvietum trilobae, without $R$. chalepensis, and Lygeo sparti-Stipetea tenacissimae.

These environmental differences are reflected in a higher number of compounds in naturalness conditions of Sf1 with 48 compounds (less disturbed site) in respect to Sf 2 with 42 compounds (more disturbed site), with 6 exclusive of Sf1, and 42 of sharing (Table 5). Of particular interest is the presence of borneol, this compound only in Sf1 having a broad spectrum antibacterial activity [54].

In Sf1, the most abundant phytochemicals were eucalyptol (40\%), camphor (15\%), camphene $(6 \%), \alpha$-pinene $(5 \%)$, and cis-thujone $(4 \%)$, while the other compounds were almost lower than 3\%. In Sf2, the main components are eucalyptol (60\%), cis-thujone (5\%), $\alpha$-pinene (4\%), $\alpha$-terpineol (3\%), and $\beta$-myrcene (4\%), while the other constituents do not exceed $2 \%$. Data available in literature on the genus Salvia show that eucalyptol (or 1.8 cineole) is usually the most abundant compound and that camphor, $\alpha$-pinene, $\beta$-pinene, and myrcene are common at different concentrations [52,55-57].

The extraction yield of EOs in $S$. fruticosa showed an average of $0.62 \%$ and a higher value in Sf $2(+19 \%$ of the mean, $p<0.05)$ than in Sf1.

Eucalyptol (1,8-cineole) is a monocyclic monoterpene found mainly in the Eucalyptus genus [58], from which it took its name, and it is a moderately effective antimicrobial agent. Therefore, plants rich in this compound usually rely on the synergetic effect with the other secondary phtyochemicals to exert their potent antimicrobial activity [59].

Finally, data seem to show that in better naturalness condition (Sf1), which meets with its typical vegetation or a high vegetation coverage and plant biodiversity, S. fruticosa yields from a moderately to a higher concentration (eucalyptol being an exception) and diversity of chemical compounds than in disturbed conditions (Sf2).

\subsection{Satureja montana L. subsp. Montana}

S. montana subsp. montana is a plant belonging to the Satureja L. genus which embraces over 30 species [60]. It is an annual or perennial semi-bushy plant that grows wild in the eastern part of the Mediterranean region [61] and in arid, sunny, stony, and rocky habitats [62]. Also known in Italy as "Santoreggia montana", this plant has been proven to possess antimicrobial, digestive, laxative, and diuretic properties, making it worthy for cultivation and to be used on an industrial scale [63]. The most abundant components of $S$. genus extracts are the phenolic phytochemicals thymol and carvacrol [62] (Figure 4). 


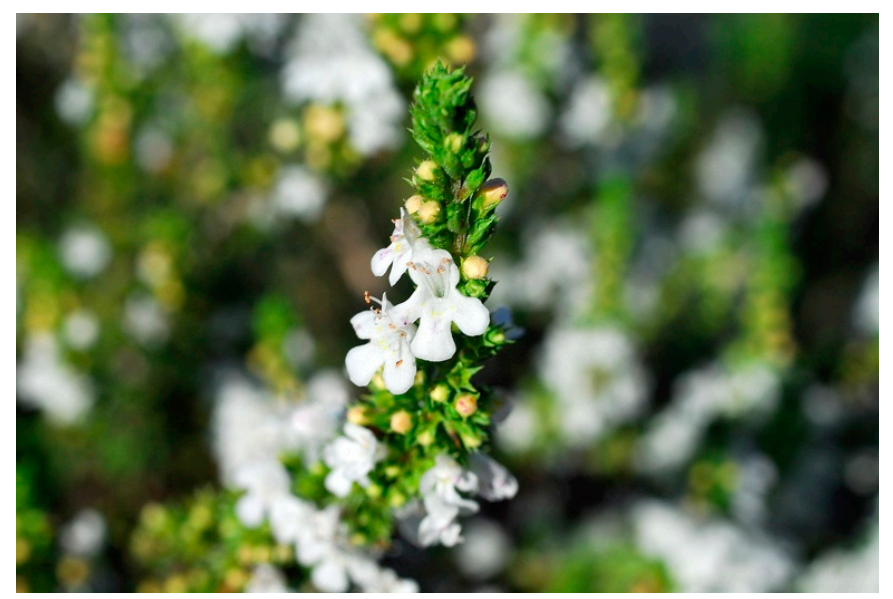

(a)

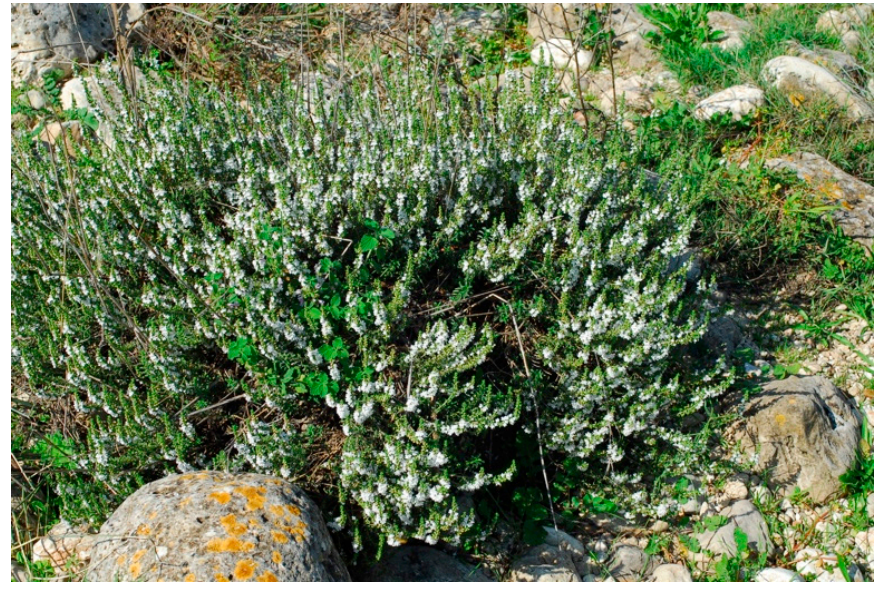

(b)

Figure 4. Satureja montana L. subsp. montana: (a) in flowering; (b) in its habitat, Asyneumo limonifolii-Saturejetum montanae, Biondi \& Guerra 2008.

However, the literature has revealed large variations in the abundance of major components such as $\gamma$-terpinene (1 to $31 \%$ ), p-cymene (3 to $27 \%$ ), linalool (1 to $62 \%$ ), and carvacrol (5 to 69\%) [64]. These differences are due to the existence of different chemotypes, though differences are also much influenced by the sites, environmental conditions, and the plant vegetative state [62].

The vegetation of this taxon was detected in Difesa di Malta (Sm1) in the province of Brindisi, and Monte Castiglione (Sm2) in the province of Bari. The phytosociological data (Table 4, Sm1) related to the site near the coast (Sm1), at $34 \mathrm{~m}$ altitude, with lower rockiness $(5 \%)$ and stoniness $(5 \%)$, count 21 species with a covering of $70 \%$ of the total area, and must be referred to the Asyneumo limonifolii-Saturejetum montanae of the Festuco-Brometea class, due to few species of low coverage values with only Valantia muralis that has the highest coverage. The few species observed in this syntaxon, often with low coverage values, can be explained by the fact that this plant community grows in an agro-ecosystem, that can defined as an HNFV area (High Nature Value Farmland), within a narrow ecotonal belt, in which different types of vegetation are thickened as is evident from the transgressive species of other syntaxa, such as Cisto cretici-Micromerietea julianae, Quercetea ilicis, and Stellarietea mediae.

In a highly naturalaness environment, in the same ecopedologic context but different geopedology (Tables 2 and 4), on the eastern side of Monte Castiglione in the Alta Murgia National Park, at $478 \mathrm{~m}$ altitude, a garrigue was detected with S. montana subsp. montana (Table 2, Sm2), to be referred to the Hyppocrepido glaucae-Stipion austroitalicae alliance. This vegetation represented the main plant community in the surveyed area, which included also many species referred to the Lygeo sparti-Stipetea tenacissimae class, mainly for Hyparrhenia hirta subsp. hirta and Asphodelus ramosus subsp. ramosus, both with high coverage. A high coverage of this species suggests that this site has a high grazing load, as this species is not eaten by livestock (mostly sheep). Other different topographic data between the two sites, such as a stronger slope $\left(35^{\circ}\right)$ and rockiness $(25 \%)$ in the Monte Castiglione site, explain better the differences on their plant communities. Finally, it should be indicated that the phenological stages of sampled species were comparable (no flowering) in both stations due to low temperatures that persisted until the end of April 2019.

These environmental and vegetational differences have been confirmed by laboratory data, with strong differences in their chemical complexity and abundance of compounds (Table 5).

The S. montana subsp. montana population coast (Sm1) contained 61 constituents with $\alpha$-pinene (27\%) having the strongest presence, followed respectively by $\alpha$-terpineol $(15.7 \%)$, trans- $\beta$-ocimene (11\%), linalool $(7.4 \%)$, and D-limonene $(7 \%)$. Pinene is a major 
monoterpene usually present in rosemary and lavender. It is known for its insecticidal properties and has two active constituent isomers: $\alpha$ - and $\beta$-pinene. The antimicrobial activity of this phytochemical was always under debate with literature indicating the presence of such potential $[65,66]$ and other studies opposing these claims $[67,68]$.

The interland poluplation (Sm2) exhibited 60 compounds. The two populations (Sm1 and Sm2) share 55 compouns, whereas 3 are exclusive of Sm1 and 3 of Sm2. Only $\alpha$ terpineol, dl-limonene, and trans- $\beta$-ocimene with, respectively, $15.2 \%, 7 \%$, and $11.4 \%$ in Sm1 underwent, respectively, a strong reduction to $0.3 \%, 0.61 \%$, and $1.98 \%$ in Sm2, while for other compounds like $\gamma$-terpinen the performance was just the opposite: important compounds in the Sm2 become traces in Sm1. Thymol was the most abundant compound in Sm2, representing 46\% of its total composition and is almost absent in Sm1. Finally, $\beta$-bisabolene, representing 3.5\% of the total area in Sm2, was not detected in Sm1.

The EOs yield of $S$. montana subsp. montana populations showed the highest observed values during this experimentation with an average of $0.90 \%$ and no significative difference between Sm1 and Sm2.

Terpineol is present in the $\alpha$ form in both Sm1 and Sm2, though it is a monoterpene alcohol commonly used in perfumes and cosmetics and studies have indicated its excellent antimicrobial activity and its ability to alter the morphology of the pathogenic and carcinogenic microorganisms $[69,70]$. As for $\beta$-ocimene, it is present, especially in Sm 1 , but it is a monoterpene that can play only the role of insect attractants [71] with no notable antimicrobial activities.

\subsection{Thymbra capitata (L.) Cav.}

T. capitata (L.) Cav. (synonym: Thymus capitatus (L.) Hoffmanns. \& Link, and Coridothymus capitatus (L.) Rchb. f.) is a perennial shrubby plant that spreads mostly around the eastern Mediterranean coast. It flowers during May and June [72] and occurs in sunny, dry, and rocky places, roadsides, and occasionally on waste grounds or sand dunes [73] at altitudes up to $600 \mathrm{~m}$ above sea level [21]. T. capitata is the main representative of the genus in the south of Italy [74]. It is one of the most researched officinal species with hundreds of studies analyzing its antimicrobial, antioxidant, anti-inflammatory, and insecticidal properties. These studies have unanimously concluded that the bioactivity of EOs is mainly correlated to the presence of monoterpenes (represented by carvacrol and thymol) that can make up almost $90 \%$ of its composition [72,75] (Figure 5).

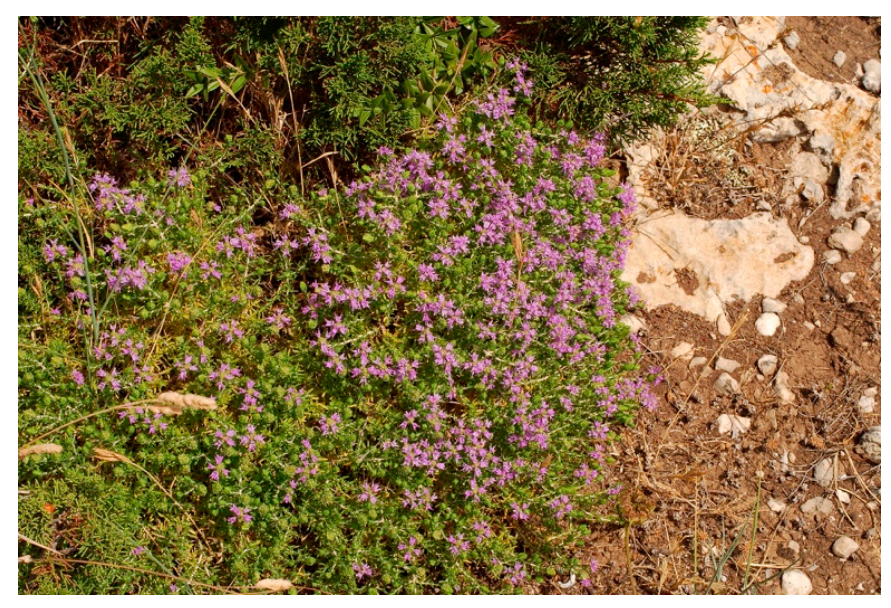

(a)

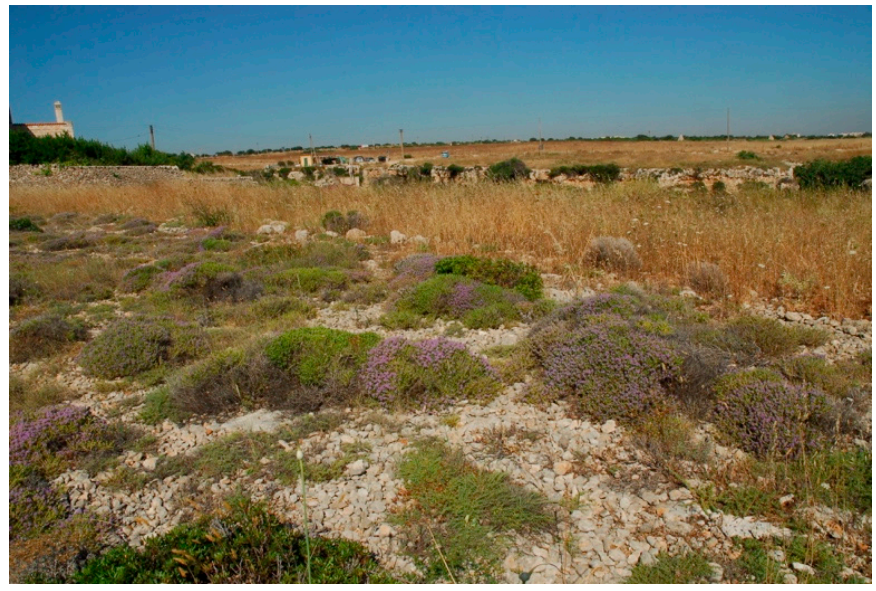

(b)

Figure 5. Thymbra capitata (L.) Cav. (a) in flowering; (b) in its maritime habitat.

The vegetation of this taxon was detected at Gravina Capo di Gavito (Tc1) in the province of Taranto (indicated also as Mottola), and Torre Santa Sabina (Tc2) in the province of Brindisi. The Gravina Capo di Gavito site is located at $236 \mathrm{~m}$ altitude, a $15^{\circ}$ slope 
and S-SE exposition, with low rockiness (2\%), and a slightly higher stoniness $(10 \%)$. The phytosociological table (Table 4) lists 36 species covering $95 \%$ of the surveyed area. The vegetation in which T. capitata grows is ascribable to Asyneumo limonifolii-Saturejetum montanae association of Cisto cretici-Micromerietea julianae class. A high number of species of high coverage were identified, indicating a strong competition with individuals of $T$. capitata. Phlomis fruticosa, a diagnostic species of Cisto cretici-Ericion manipuliflorae alliance, had the highest coverage, followed by S. montana subsp. montana. Two transgressive classes were observed, Lygeo-Stipetea (perennial grasslands) through several species, such as Charybdis pancration and Hypochaeris achyrophorus, as well as the Stellarietea mediae class.

Torre Santa Sabina is a maritime site with a lower altitude $(7 \mathrm{~m})$ than Gravina Capo di Gavito, as well as a lower slope $\left(2^{\circ}\right)$, a NE exposition with equal low rockiness $(2 \%)$ and stoniness (10\%). In this site, T. capitata has a higher coverage than Gravina Capo di Gavito and follows the same phytosociological syntaxa. The highest coverage was observed with species referred to the Cisto cretici-Ericion manipuliflorae alliance, mainly Cistus monspeliensis (3) and C. creticus subsp. eriocephalus (2). The transgressive Tuberarietea guttatae class was observed only in this site.

The relationship between the two sites showed two slightly different conditions within the same class Cisto cretici-Ericion manipuliflorae. The association Asyneumo limonifoliiSaturejetum montanae was only detected in the relief of Gravina Capo di Gavito due to the presence of a high coverage of $S$. montana subsp. montana. The most significant difference between the two sites concern their climatic, geolithological, ecopedologic, and topographical aspects, such as altitudes, continentality (maritime factors in Santa Sabina site), and exposure, that makes the Torre Santa Sabina site cooler than that in the province of Taranto, confirmed also by different transgressive syntaxa observed, except the LygeoStipetea class (perennial grasslands, more abundant in Gravina Capo di Gavito), common in both sites.

The higher presence of species of the Quercetea ilicis class in the Torre Santa Sabina site seems to suggested a better conservation status of the habitat than the Mottola one, where the observation of Stellarietea mediae class species seems to indicate the presence of an anthropic disturbance as witnessed also by the presence of Centranthus macrosiphon, an alien naturalized species.

The GC-MS results of Tc1 show the presence of 51 compounds, with the most abundant ones being thymol (31\%), carvacrol (26\%), $\gamma$-terpinene $(15.4 \%)$, and p-cymene $(9.5 \%)$. As for Tc2, 50 compounds were detected. The most abundant ones were the same as Tc1 with differences in percentages. Thymol with the strongest presence $(36 \%)$, followed by $\gamma$-terpinene $(18 \%)$, carvacrol (decreased to $17 \%)$, and p-cymene $(10 \%)$. The rest of the compounds did not exceed 3\%. Low differences were observed in the compounds abundance and patterns for the two samples surveyed in different ecological contexts. The two populations shared 50 compounds, while only cis-thujone was exclusive of Tc1. As regards the EOs extraction yield, T. capitata had a mean value of $0.54 \%$ and Tc1 reported a significative $(p<0.05)$ higher value than Tc2 $(+22 \%$ of the mean).

Thymol and carvacrol are monoterpene phenols that appear in many EOs of the Lamiaceae family. These compounds have been highly studied and have been proven to possess strong antimicrobial activities against a wide range of microorganisms [76].

$\Gamma$-terpinene is a monoterpene, usually present in different plant varieties [77], which can exhibit antioxidant and antimicrobial properties against several microorganisms [78,79].

Results for both populations are in agreement with published data; the major compounds of T. capitata are usually carvacrol and thymol which are known for their strong biological activities and their amount may be as high as $90 \%$ of the total EOs composition [75,80-82]. Thus, T. capitata may be considered a potential source of antimicrobial phytochemicals. 


\subsection{Syntaxonomical Scheme}

See below

Quercetea ilicis Br.-Bl. in Br.-Bl., Roussine \& Nègre 1952

Pistacio lentisci-Rhamnetalia alaterni- Rivas-Martínez 1975

Oleo sylvestris-Ceratonion siliquae Br.-Bl-, ex- Guinochet \& Drouineau 1944

Ruto chalepensis-Salvietum trilobae- Biondi \& Guerra 2008

Cisto cretici-Micromerietea julianae, Oberdorfer 1954- ex Horvatic 1958

Cisto cretici-Ericetalia manipuliflorae- Horvatic 1958

Cisto cretici-Ericion manipuliflorae- Horvatic 1958

Asyneumo limonifolii-Saturejetum montanae- Biondi \& Guerra 2008

Festuco-Brometea Br.-Bl.- et Tx. 1943- ex Klika \& Hadac 1944 (habitat 62A0)*

Scorzonero-Chrysopogonetalia- Horvatic \& Horvat (1956) 1958

Hippocrepido glaucae-Stipion austroitalicae- Forte et Terzi in Forte, Perrino \& Terzi 2005

Acinos suaveolentis-Stipetum austroitalicae- Forte \& Terzi in Forte, Perrino \& Terzi 2005

\section{Conclusions}

Ecological research was conducted in order to know if plant communities' topographic, geopedological, and ecopedological conditions can induce and/or explain differences in chemical composition of essential oils (EOs). In Satureja montana subsp. montana, environmental and plant community differences induced significant variations in the abundance of bioactive phytochemicals such as thymol and $\gamma$-terpinene. In particular, the EOs from Salvia fruticosa had specific differences in their chemical complexity and abundance of components. Passing to Thymbra capitata, in Gravina Capo di Gavito (population Tc1), at higher altitude and high plant species coverage, a good production in EOs was observed compared to the coastal population from Torre Santa Sabina (Tc2).

In general, the results showed that there is an interaction, positive or negative, between topographic factors, including plant communities, and yields of EOs. The understanding of such aspects and, more specifically, the knowledge of how and why it happens is very important to design projects aiming to improve valorization and conservation of biodiversity of wild plant species and especially of conservation interest.

The study has provided new data on Clinopodium suaveolens and Salvia fruticosa subsp. thomasii, taxa that from a biochemical point of view seem to be very promising and hence potentially eligible for industrial use, as well as for the enhancement of local genetic resources.

Author Contributions: Conceptualization, E.V.P.; methodology, E.V.P., F.V., G.M.; software, E.V.P., F.V., G.M., A.T.; validation, E.V.P.; formal analysis, E.V.P., F.V., G.M., A.T.; investigation, E.V.P., F.V., G.M.; data curation, E.V.P., F.V., G.M., A.T.; writing—original draft preparation, E.V.P.; writingreview and editing, E.V.P., F.V., G.M., A.G., A.T.; visualization, E.V.P., F.V., G.M., A.G., A.T.; supervision, E.V.P.; pictures, E.V.P. All authors have read and agreed to the published version of the manuscript.

Funding: This research received no external funding.

Institutional Review Board Statement: Not applicable.

Informed Consent Statement: Not applicable.

Data Availability Statement: Not applicable.

Conflicts of Interest: The authors declare no conflict of interest.

\section{References}

1. Aziz, M.A.; Ullah, Z.; Pieroni, A. Wild Food Plant Gathering among Kalasha, Yidgha, Nuristani and Khowar Speakers in Chitral, NW Pakistan. Sustainability 2020, 12, 9176. [CrossRef]

2. Singh, B.; Singh, B.; Kishor, A.; Singh, S.; Bhat, M.N.; Surmal, O.; Musarella, C.M. Exploring Plant-Based Ethnomedicine and Quantitative Ethnopharmacology: Medicinal Plants Utilized by the Population of Jasrota Hill in Western Himalaya. Sustainability 2020, 12, 7526. [CrossRef] 
3. Maruca, G.; Spampinato, G.; Turiano, D.; Laghetti, G.; Musarella, C.M. Ethnobotanical notes about medicinal and useful plants of the Reventino Massif tradition (Calabria region, Southern Italy). Genet. Resour. Crop Evol. 2019, 66, 1027-1040. [CrossRef]

4. Musarella, C.M.; Paglianiti, I.; Spampinato, G. Ethnobotanical study in the Poro and Preserre Calabresi territory (Vibo Valentia, S-Italy). Atti Soc. Tosc. Sci. Nat. Mem. Serie. B 2019, 126, 13-28. [CrossRef]

5. Ahmad, M.; Sultana, S.; Fazl-I-Hadi, S.; Ben Hadda, T.; Rashid, S.; Zafar, M.; Khan, M.A.; Khan, M.P.; Yaseen, G. An ethnobotanical study of medicinal plants in high mountainous region of Chail valley (District Swat-Pakistan). J. Ethnobiol. Ethnomedicine 2014, 10, 36-53. [CrossRef] [PubMed]

6. Sargin, S.A.; Büyükcengiz, M. Plants used in ethnomedicinal practices in Gulnar district of Mersin, Turkey. J. Herb. Med. 2019, 15, 100224. [CrossRef]

7. Maksimović, M.; Vidic, D.; Miloš, M.; Šolić, M.E.; Abadžić, S.; Siljak-Yakovlev, S. Effect of the environmental conditions on essential oil profile in two Dinaric Salvia species: S. brachyodon Vandas and S. officinalis L. Bioch. Syst. Ecol. 2018, 35, 473-478. [CrossRef]

8. Yeddes, W.; Wannes, W.A.; Hammami, M.; Smida, M.; Chebbi, A.; Marzouk, B.; Tounsi, M.S. Effect of environmental conditions on the chemical composition and antioxidant activity of essential oils from Rosmarinus officinalis L. growing wild in Tunisia. J. Essent. Oil Bear. Plants 2018, 21, 972-986. [CrossRef]

9. Mastinu, A.; Bonini, S.A.; Premoli, M.; Maccarinelli, G.; Mac Sweeney, E.; Zhang, L.; Lucini, L.; Memo, M. Protective Effects of Gynostemma pentaphyllum (var. Ginpent) against Lipopolysaccharide-Induced Inflammation and Motor Alteration in Mice. Molecules 2021, 26, 570. [CrossRef]

10. Perrino, E.V.; Brunetti, G.; Farrag, K. Plant communities of multi-metal contaminated soils: A case study in National Park of Alta Murgia (Apulia Region-Southern Italy). Int. J. Phytoremediat. 2014, 16, 871-888. [CrossRef]

11. Panuccio, M.R.; Fazio, A.; Musarella, C.M.; Mendoza-Fernández, A.J.; Mota, J.F.; Spampinato, G. Seed germination and antioxidant pattern in Lavandula multifida (Lamiaceae): A comparison between core and peripheral populations. Plant Biosyst. 2018, 152, 398-406. [CrossRef]

12. Bonsignore, C.P.; Laface, V.L.A.; Vono, G.; Marullo, R.; Musarella, C.M.; Spampinato, G. Threats Posed to the Rediscovered and Rare Salvia ceratophylloides Ard. (Lamiaceae) by Borer and Seed Feeder Insect Species. Diversity 2021, 13, 33. [CrossRef]

13. Spampinato, G.; LaFace, V.L.A.; Ortiz, A.C.; Canas, R.Q.; Musarella, C.M. Salvia ceratophylloides Ard. (Lamiaceae): A rare endemic species of Calabria (Southern Italy). In Endemic Species; Cano Carmona, E., Musarella, C.M., Cano Ortiz, A., Eds.; IntechOpen: London, UK, 2019. [CrossRef]

14. Özkan, M. Glandular and eglandular hairs of Salvia recognita Fisch. \& Mey. (Lamiaceae) in Turkey. Bang. J. Bot. $2008,37,93-95$.

15. Carović-Stanko, K.; Petek, M.; Grdiša, M.; Pintar, J.; Bedeković, D.; Ćustić, M.H.; Satovic, Z. Medicinal plants of the family of Lamiaceae as functional foods-A review. Czech J. Food Sci. 2016, 34, 377-390. [CrossRef]

16. Stefanaki, A.; Cook, C.M.; Lanaras, T.; Kokkini, S. Essential oil variation of Thymbra spicata L. (Lamiaceae), an East Mediterranean "oregano" herb. Biochem. Syst. Ecol. 2018, 80, 63-69. [CrossRef]

17. Piotto, B.; Di Noi, A. Propagazione per Seme di Alberi e Arbusti Della Flora Mediterranea; Agenzia Nazionale per la Protezione dell'Ambiente, AMPA: Roma, Italy, 2001.

18. Bellini, F.; Dursi, F.; Perrino, E.V.; Wagensommer, R.P. Caratterizzazione floristica di aree di proprietà pubblica per la reintroduzione delle specie vegetali in situ. Il parco naturale regionale Terra delle Gravine. In Grastepp tra Gravine e Steppe-Azioni per la Conservazione Della Biodiversità nel Parco Nazionale dell'Alta Murgia e nel Parco Naturale Regionale Terra Delle Gravine—Rapporto Finale. APQ FAS Biodiversità Delibera Cipe 19/2004; Ufficio Parchi e Tutela della Biodiversità della Regione Puglia: Bari, Italy, 2014; pp. 117-127.

19. Italian Ministry for the Environment, Land and Sea (MATTM) Geoportale Nazionale. 2020. Available online: http:/ /www.pcn. minambiente.it/viewer/ (accessed on 18 November 2020).

20. Braun-Blanquet, J. Plant Sociology; McGraw-Hill: New York, NY, USA, 1932; p. 439.

21. Pignatti, S. Flora d'Italia; Edagricole: Bologna, Italy, 1982; Volume 1-3.

22. Tutin, T.G.; Heywood, V.H.; Burges, N.A.; Moore, D.M.; Valentine, D.H.; Walters, S.M.; Webb, D.A. Flora Europaea: Plantaginaceae to Compositae (and Rubiaceae), 1st ed.; Cambridge University Press: Cambridge, UK, 1964; Volume 1-5, pp. $1968-1976$.

23. Bartolucci, F.; Peruzzi, L.; Galasso, G.; Albano, A.; Alessandrini, A.; Ardenghi, N.M.G.; Astuti, G.; Bacchetta, G.; Ballelli, S.; Banfi, E.; et al. An updated checklist of the vascular flora native to Italy. Plant Biosyst. 2018, 152, 179-303. [CrossRef]

24. Galasso, G.; Conti, F.; Peruzzi, L.; Ardenghi, N.M.G.; Banfi, E.; Celesti-Grapow, L.; Albano, A.; Alessandrini, A.; Bacchetta, G.; Ballelli, S.; et al. An updated checklist of the vascular flora alien to Italy. Plant Biosyst. 2018, 152, 556-592. [CrossRef]

25. Brullo, S.; Scelsi, F.; Spampinato, G. La Vegetazione dell'Aspromonte; Laruffa: Reggio Calabria, Italy, 2001.

26. Rivas-Martínez, S. Global Bioclimatics. Clasificación Bioclimática de la Tierra. 2004. Available online: http://www. globalbioclimatics.org/book/bioc/bioc1.pdf (accessed on 21 November 2020).

27. Biondi, E.; Blasi, C. Prodromo Della Vegetazione d'Italia. Check-List Sintassonomica Aggiornata di Classi, Ordini e Alleanze Presenti in Italia, Eds., Società Botanica Italiana Onlus. 2013. Available online: http:/ /www.prodromo-vegetazione-italia.org (accessed on 20 November 2020).

28. Meyer-Warnod, B. Natural essential oils: Extraction processes and application to some major oils. Perfum. Flavorist 1984, 9 , 93-104. 
29. Kováts, E. Gas chromatographische charakterisierung organischer verbindungen. Teil 1: Retentions indices aliphatischer halogenide, alkohole, aldehyde und ketone. Helv. Chim. Acta 1958, 41, 1915-1932. [CrossRef]

30. Babushok, V.I.; Linstrom, P.J.; Zenkevich, I.G. Retention indices for frequently reported compounds of plant essential oils. J. Phys. Chem. Ref. Data 2011, 40, 3-47. [CrossRef]

31. Fırat, M.; Akçiçek, E.; Kaya, A. Clinopodium serpyllifolium subsp. sirnakense (Lamiaceae), a new taxon from south-eastern Anatolia, Turkey. Phytotaxa 2015, 201, 131-139. [CrossRef]

32. Bräuchler, C.; Meimberg, H.; Heubl, G. New names in old world Clinopodium: The transfer of the species of Micromeria sect. Pseudomelissa to Clinopodium. Taxon 2006, 55, 977-981. [CrossRef]

33. Ryding, O. Revision of the Clinopodium abyssinicum group (Labiatae). Bot. J. Linn. Soc. 2006, 150, 391-408. [CrossRef]

34. Ryding, O. Revision of the Clinopodium simense group (Labiatae). Kew Bull. 2006, 61, 419-432.

35. Harley, R.M.; Granda, A.P. List of species of Tropical American Clinopodium (Labiatae), with new combinations. Kew Bull. 2000, 55, 917-927. [CrossRef]

36. Govaerts, R. World Checklist Seed Plants 3; Continental Publishing: Deurne, Belgium, 1999.

37. Harley, R.M.; Atkins, S.; Budantsev, A.L.; Cantino, P.D.; Conn, B.J.; Grayer, R.; Harley, M.M.; Kok, R.; Krestovskaja, T.; Morales, R.; et al. Labiatae. In The Families and Genera of Vascular Plants; Kaderit, J.W., Ed.; Springer: Berlin, Germany, 2004; Volume 7, pp. 238-242.

38. Greuter, W.; Burdet, H.M.; Long, G. Med-Checklist: A Critical Inventory of Vascular Plants of the Circum-Mediterranean Countries; Conservatoire et Jardin botanique de la Ville Genève: Genève, Switzerland, 1986; p. 395.

39. Conti, F.; Manzi, A.; Pedrotti, F. Liste Rosse Regionali delle Piante d'Italia; WWF Italia, Società Botanica Italiana, CIAS: Camerino, Italy, 1997.

40. Forte, L.; Terzi, M.; Perrino, E.V. Le praterie a Stipa austroitalica Martinovský ssp. austroitalica dell'Alta Murgia (Puglia) e della Murgia Materana (Basilicata). Fitosociologia 2005, 42, 83-103.

41. Perrino, E.V.; Cavallaro, V. Flora delle praterie di Monte Castiglione (Alta Murgia-Puglia). Interdipendenze 2011, 3, 31-45.

42. Oberdorfer, E. Nordaegaeische Kraut-und Zwergstrauchflurenim Vergleichmit den entsprechenden Vegetationseinheiten des westlichen Mittelmeergebietes. Vegetatio 1954, 5, 88-96. [CrossRef]

43. Horvat, I.; Glavač, V.; Ellenberg, H. Vegetation Südosteuropas; Fischer: Stuttgart, Germany, 1974; p. 752.

44. Brullo, S.; Minissale, P.; Spampinato, G. La classe Cisto-Micromerietea nel Mediterraneo centrale e orientale. Fitosociologia 1997, 32, 29-60.

45. Kaya, A. Morphological characteristics of Clinopodium acinos and Clinopodium suaveolens (Lamiaceae) growing in Turkey. J. Res. Pharm. 2019, 23, 62-68. [CrossRef]

46. Stojanović, G.; Golubović, T.; Kitić, D.; Palić, R. Acinos species: Chemical composition, antimicrobial and antioxidative activity. J. Med. Plants Res. 2009, 3, 1240-1247.

47. Baser, K.H.C.; Kirimer, N.; Tumen, G. Pulegone-rich essential oils of Turkey. J. Essent. Oil Res. 1998, 10, 1-8. [CrossRef]

48. Karousou, R.; Balta, M.; Hanlidou, E.; Kokkini, S. "Mints", smells and traditional uses in Thessaloniki (Greece) and other Mediterranean countries. J. Ethnopharmacol. 2007, 109, 248-257. [CrossRef]

49. Da Rocha, M.S.; Dodmane, P.R.; Arnold, L.L.; Pennington, K.L.; Anwar, M.M.; Adams, B.R.; Taylor, S.V.; Wermes, C.; Adams, T.B.; Cohen, S.M. Mode of action of pulegone on the urinary bladder of F344 rats. Toxicol. Sci. 2012, 128, 1-8. [CrossRef]

50. Kokkalou, E. Composition of the volatile oil from Acinos suaveolens. Planta Med. 1988, 4, 340-342. [CrossRef] [PubMed]

51. Božovìc, M.; Ragno, R. Calamintha nepeta (L.) Savi and its main essential oil constituent pulegone: Biological activities and chemistry. Molecules 2017, 22, 290. [CrossRef]

52. Cvetkovikj, I.; Stefkov, G.; Karapandzova, M.; Kulevanova, S. Essential oil composition of Salvia fruticosa Mill. populations from Balkan peninsula. Maced. Pharm. Bull. 2015, 61, 19-26. [CrossRef]

53. Perrino, E.V.; Wagensommer, R.P. Habitats of directive 92/43/EEC in the National park of Alta Murgia (Apulia-Southern Italy): Threat, action and relationships with plant communities. J. Environ. Sci. Eng. (A) 2013, 2, 229-235.

54. Yang, L.; Zhan, C.; Huang, X.; Hong, L.; Fang, L.; Wang, W.; Su, J. Durable Antibacterial Cotton Fabrics Based on Natural Borneol-Derived Anti-MRSA. Agents. Adv. Healthc. Mater. 2020, 9, 2000186. [CrossRef] [PubMed]

55. Giweli, A.A.; Džamić, A.M.; Socović, M.; Ristić, M.S.; Janaćković, P.; Marin, P.D. The chemical composition, antimicrobial and antioxidant activities of the essential oil of Salvia fruticosa growing wild in Libya. Arch. Biol. Sci. 2013, 65, 321-329. [CrossRef]

56. Sarrou, E.; Martens, S.; Chatzopoulou, P. Metabolite profiling and antioxidative activity of Sage (Salvia fruticosa Mill.) under the influence of genotype and harvesting period. Ind. Crops Prod. 2016, 94, 240-250. [CrossRef]

57. Tundis, R.; Loizzo, M.R.; Bonesi, M.; Leporini, M.; Menichini, F.; Passalacqua, N.G. A study of Salvia fruticosa Mill subsp. thomasii (Lacaita) Brullo, Guglielmo, Pavone and Terrasi, an endemic sage of southern Italy. Plant Biosyst. 2016, 152, 130-141. [CrossRef]

58. Sebei, K.; Sakouhi, F.; Herchi, W.; Khouja, M.L.; Boukhchina, S. Chemical composition and antibacterial activities of seven Eucalyptus species essential oils leaves. Biol. Res. 2015, 48, 7. [CrossRef]

59. Safaei-Ghomi, J.; Ahd, A.A. Antimicrobial and antifungal properties of the essential oil and methanol extracts of Eucalyptus largiflorens and Eucalyptus intertexta. Pharmacogn. Mag. 2010, 6, 172-175. [CrossRef]

60. Vidic, D.; Maksimović, M.; Cavar, S.; Solic, M.E. Comparison of essential oil profiles of Satureja montana L. and endemic Satureja visianii Šilic. J. Essent. Oil Bear. Plants 2009, 12, 273-281. [CrossRef] 
61. ćavar, S.; Maksimović, M.; Šolić, M.E.; Jerković-Mujkić, A.; Bešta, R. Chemical composition and antioxidant and antimicrobial activity of two Satureja essential oils. Food Chem. 2008, 111, 648-653. [CrossRef]

62. Bezbradica, D.I.; Tomovic, J.M.; Vukasinovic, M.S.; Siler-Marinkovic, S.; Ristic, M.M. Composition and antimicrobial activity of essential oil of Satureja montana L. collected in Serbia and Montenegro. J. Essen. Oil Res. 2005, 17, 462-465. [CrossRef]

63. Caprioli, G.; Lupidi, G.; Maggi, F. Comparison of chemical composition and antioxidant activities of two winter savory subspecies (Satureja montana subsp. variegata and Satureja montana subsp. montana) cultivated in Northern Italy. Nat. Prod. Res. 2018, 33, 3143-3147. [CrossRef] [PubMed]

64. Piccaglia, R.; Marroti, M.; Galletti, G.C. Characterization of essential oils from Saturea montana L. chemotype grown in Northen Italy. J. Essen. Oil. Res. 1991, 3, 147-152. [CrossRef]

65. Leite, A.M.; Lima, E.D.O.; de Souza, E.L.; Diniz, M.D.F.F.M.; Trajano, V.N.; de Medeiros, I.A. Inhibitory effect of $\beta$-pinene, $\alpha$-pinene and eugenol on the growth of potential infectious endocarditis causing Gram-positive bacteria. Rev. Bras. Cienc. Farm. 2007, 43, 121-126. [CrossRef]

66. da Silva, A.C.R.; Lopes, P.M.; de Azevedo, M.M.B.; Costa, D.C.; Alviano, C.S.; Alviano, D.S. Biological activities of $\alpha$-pinene and $\beta$-pinene enantiomers. Molecules 2012, 17, 6305-6316. [CrossRef]

67. Angelini, L.G.; Carpanese, G.; Cioni, P.L.; Morelli, I.; Macchia, M.; Flamini, G. Essential oils from Mediterranean Lamiaceae as weed germination inhibitors. J. Agric. Food Chem. 2003, 51, 6158-6164. [CrossRef]

68. Koutsoudaki, C.; Krsek, M.; Rodger, A. Chemical composition and antibacterial activity of the essential oil and the gum of Pistacia lentiscus var. chia. J. Agric. Food Chem. 2005, 53, 7681-7685. [CrossRef] [PubMed]

69. Park, S.N.; Lim, Y.K.; Freire, M.O.; Cho, E.; Jin, D.; Kook, J.K. Antimicrobial effect of linalool and $\alpha$-terpineol against periodontopathic and cariogenic bacteria. Anaerobe 2012, 18, 369-372. [CrossRef]

70. Li, J.; Xie, S.; Ahmed, S.; Wang, F.; Gu, Y.; Zhang, C.; Chai, X.; Wu, Y.; Cai, J.; Cheng, G. Antimicrobial Activity and Resistance: Influencing Factors. Front. Pharmacol. 2017, 8, 364. [CrossRef]

71. Farré-Armengol, G.; Filella, I.; Llusià, J.; Peñuelas, J. $\beta$-Ocimene, a Key Floral and Foliar Volatile Involved in Multiple Interactions between Plants and Other Organisms. Molecules 2017, 22, 1148. [CrossRef] [PubMed]

72. Condurso, C.; Verzera, A.; Ragusa, S.; Tripodi, G.; Dima, G. Volatile composition of Italian Thymus capitatus (L.) Hoffmanns. et Link leaves. J. Essen. Oil Res. 2013, 25, 239-243. [CrossRef]

73. Tscheulin, T.; Petanidou, T. Does spatial population structure affect seed set in pollen-limited Thymus capitatus? Apidologie 2011, 42, 67-77. [CrossRef]

74. Russo, M.; Suraci, F.; Postorino, S.; Serra, D.; Roccotelli, A.; Agosteo, G.E. Essential oil chemical composition and antifungal effects on Sclerotium cepivorum of Thymus capitatus wild populations from Calabria, southern Italy. Rev. Bras. Farmacogn. 2013, 23, 239-248. [CrossRef]

75. Akrout, A.; El Jani, H.; Amouri, S.; Neffati, M. Screening of antiradical and antibacterial activities of essential oils of Artemisia campestris L.; Artemisia helba Alba Asso, and Thymus capitatus Hoff. et Link. growing wild in the southern of Tunisia. Recent Res. Sci. Technol. 2010, 2, 29-39.

76. Memar, M.Y.; Raei, P.; Alizadeh, N.; Aghdam, M.A.; Kafil, H.S. Carvacrol and thymol: Strong antimicrobial agents against resistant isolates. Rev. Med. Microbiol. 2017, 28, 63-68. [CrossRef]

77. Ramalho, T.R.D.O.; de Oliveira, M.T.; Lima, A.L.D.A.; Bezerra-Santos, C.R.; Piuvezam, M.R. Gamma-terpinene modulates acute inflammatory response in mice. Planta Med. 2015, 81, 1248-1254. [CrossRef] [PubMed]

78. Oyedemi, S.O.; Okoh, A.I.; Mabinya, L.V.; Pirochenva, G.; Afolayan, A.J. The proposed mechanism of bactericidal action of eugenol, $\alpha$-terpineol and $\gamma$-terpinene against Listeria monocytogenes, Streptococcus pyogenes, Proteus vulgaris and Escherichia coli. Afr. J. Biotechnol. 2009, 8, 1280-1286.

79. Giweli, A.A.; Džamić, A.M.; Socović, M.; Ristić, M.S.; Marin, P.D. Antimicrobial and antioxidant activities of essential oils of Satureja thymbra growing wild in Libya. Molecules 2012, 17, 4836-4850. [CrossRef] [PubMed]

80. Tabti, L.; Dib, M.E.A.; Gaouar, N.; Samira, B.; Tabti, B. Antioxidant and antifungal activity of extracts of the aerial parts of Thymus capitatus (L.) Hoffmanns against four phytopathogenic fungi of Citrus sinensis. Jundishapur J. Nat. Pharm. Prod. 2014, 9, 49-54. [CrossRef] [PubMed]

81. Marin, M.; Novakovic, M.; Vuckovic, I.; Teševic, V.; Kolarevic, S.; Vukovic-Gacic, B. Wild Thymus capitatus Hoff. Et Link. chemical composition, antioxidant and antimicrobial activities of the essential oil. J. Essent. Oil Bear. Plants 2018, 21, 388-399. [CrossRef]

82. Salehi, B.; Abu-Darwish, M.S.; Tarawneh, A.H.; Cabral, C.; Gadetskaya, A.V.; Salgueiro, L.; Hosseinabadi, T.; Rajabi, S.; Chanda, W.; Sharifi-Rad, M.; et al. Thymus spp. Plants-Food applications and phytopharmacy properties. Trends Food Sci. Technol. 2019, 85, 286-306. [CrossRef] 